\title{
VEGETATION HETEROGENEITY OF BLACK ALDER FORESTS IN AND AROUND EL-KALA BIOSPHERE RESERVE, NORTHEASTERN ALGERIA
}

\section{HETEROGENEIDAD DE LA VEGETACIÓN DE LOS BOSQUES DE ALISO NEGRO EN Y ALREDEDOR de la Reserva de la Biosfera El-Kala, nOREste de ARgelia}

\author{
Abdeldjabar NeCer ${ }^{1,2 *}$, Aicha Tadjine ${ }^{1,2}$, DJamila Belouahem-Abed $^{3}$, And Messaoud SaOudi $^{1,2}$
}

${ }^{1}$ Faculty of Natural and Life Sciences, Department of Biology, University of Chadli Bendjedid, El-Tarf, Algeria

${ }^{2}$ Laboratory of Functional and Evolutionary Ecology, University of Chadli Bendjedid, El-Tarf, Algeria

${ }^{3}$ National Institute of Forestry Researches, El-Kala Research Station, El-Tarf, Algeria

* Corresponding author: tabet.necer@gmail.com

\begin{abstract}
Background: Despite its ecological importance, the study of Algerian alder forests has been largely neglected, even though they represent the largest ones of their kind in North Africa. Moreover, few measures have been taken towards the protection of these ecosystems.

Questions: How many species are present in the Algerian alder forests? What is the effect of soil properties on species richness and diversity of inventoried plants? Are its spatial patterns related to soil variables variation?

Studied species: Polypodiopsida, Gymnospermae, and Angiospermae.

Study site and dates: El-Kala Biosphere Reserve (KBR) and surroundings, El-Tarf province, northeastern Algeria, from January 2016 to February 2017.

Methods: Twenty-eight localities were sampled using the relevé method. Soil samples were taken from three points at each site. The relationship between species richness and soil factors was statistically evaluated using multiple linear regression and multivariate statistical analysis.

Results: The inventory showed a total of 352 species that belong to 236 genera and 89 families. According to NMDS ordination, black alder forests were classified into two groups (marshy and hilly forests, and fluvial forests), in relation to plant species richness. No linear relationships between species richness and soil parameters were observed, except for OM $(P=0.013)$.

Conclusion: The present study demonstrated a relatively high plant diversity characterizing alder forests of this region. To some extent, such diversity is related to the heterogeneous distribution of plant species among different habitat types. Those factors that affect its zonation were identified, for this ecosystem, our study revealed that vegetation diversity is related to the spatial variation of soil variables.
\end{abstract}

Key words: Alnus glutinosa; Biosphere Reserve, Floristic richness, North Africa, Northeastern Algeria.

\section{Resumen}

Antecedentes: A pesar de su importancia ecológica, son pocos los estudios sobre los bosques de aliso en Argelia, los cuales constituyen los más grandes en África del Norte. Además, estos ecosistemas carecen de medidas de protección.

Preguntas: ¿Cuántas especies están presentes en los los bosques de aliso argelinos? ¿Qué efecto tienen los factores abióticos (características de suelo) sobre la riqueza de especies y la diversidad de plantas? ¿Están relacionados sus patrones espaciales con la variación de los factrores edáficos?

Especies estudiadas: Polypodiopsida, Gymnospermae y Angiospermae.

Sitio y años de estudio: Reserva de la Biosfera El-Kala (KBR), provincia de El-Tarf, nordeste de Argelia, desde enero de 2016 hasta febrero de 2017.

Métodos: Se muestreó la vegetación en 28 sitios de bosques de aliso negro (Alnus glutinosa (L.) Gaertn.). Además, se tomaron muestras de suelo de tres puntos en cada sitio. La relación entre la riqueza de especies y los factores ambientales se evaluó mediante regresión lineal múltiple y análisis estadístico multivariado.

Resultados: El inventario contiene en total 352 especies pertenecientes a 236 géneros y 89 familias. De acuerdo con los resultados de la ordenación NMDS, los bosques de aliso negro se clasificaron en dos grupos (bosques de pantano y de colina, y bosques fluviales), en relación con la riqueza de especies. No se observó ninguna relación lineal entre la riqueza de especies y los parámtetros de suelo, excepto para MO $(P=0.013)$.

Conclusión: El presente estudio demonstró que existe una diversidad de plantas relativamente alta en los bosque de aliso de esta región. En gran medida, esta diversidad está relacionada con la distribución heterogénea de las especies entre los diferentes hábitats. Se logró identificar cuáles factores afectan su zonación: para este ecosistema, nuestro estudio reveló que la diversidad de la vegetación está relacionada con la variación espacial de las variables edáficas.

Palabras clave: Alnus glutinosa; África del Norte; nordeste de Argelia; Reserva de la Biosfera; Riqueza florística.

This is an open access article distributed under the terms of the Creative Commons Attribution License CCBY-NC (4.0) international. https://creativecommons.org/licences/by-nc/4.0/ 
Black alder (Alnus glutinosa (L.) Gaertn.) forests are ecosystems naturally widespread across all of Europe, from southern Scandinavia to the Mediterranean countries, including some regions of North Africa, namely northern Morocco and northeastern Algeria (Jalas \& Suominen 1976, Kajba \& Gracan 2003). Black alder forest is one type of broadleaved forest, and it has a broad but highly scattered distribution (it represents less than $1 \%$ of forest cover in most countries). Despite this spatial configuration, the total population size of this species is not yet thought to approach threshold values to warrant its inclusion in a threatened category. Thus, the species is listed as Least Concern in the IUCN Red List (Shaw et al. 2014).

Black alder forest is a particular kind of wetland forest. Black alder occurrence is closely related to water availability and high atmospheric humidity during all phases of its reproductive cycle (Bensimon 1985). It commonly occurs in hilly regions, alongside streams and rivers banks, in damp marshy woods and riverside woodlands (Shaw et al. 2014). According to Claessens (2003), black alder forests occur in three main types of wetlands: (i) marshy or swampy sites with sodden soil throughout the year, which constitute the Alnetum community; (ii) riverside sites in which the soil in the rooting zone is well aerated during the growing season (Alno-Padion community); and (iii) hilly sites with high soil humidity (Carpinion community).

Black alder is recognized as an important contributor to forest structure in other wetland ecosystems, and it contributes to the services which they offer (Claessens 2003). For example, Alnus glutinosa plays a key role in biodiversity maintenance by offering habitats for specific flora and fauna, both on the tree itself and in the flooded root system (Dussart 1999). This ecosystem contributes to water filtration and purification in flooded soils (Pinay \& Labroue 1986, Schnitzler-Lenoble \& Carbiener 1993) because the root system of black alder helps control floods and stabilize riverbanks (Piégay et al. 2003).

In Algeria, few studies have been conducted on alder forests. This is regrettable, as these forests constitute the largest ones in North Africa (Belouahem et al. 2011, Bensettiti \& Lacoste 1999, Géhu et al. 1994), and few measures have been taken to protect these ecosystems. In fact, only two sites benefit from indirect conservation measures, based on freshwater bird richness (alder forests of Tonga, and those of Ain Khiar, were classified as RAMSAR sites in 1983 and 2002, respectively).

Identifying species composition and the existing species assemblages, and examining how these species are distributed across the alder forest region in northeastern Algeria, are necessary steps prior to investigating the functioning and dynamics of these ecosystems. Algerian black alder forests represent an extremely original ecosystem of northern affinity throughout North Africa (Géhu et al. 1994) and are characterized by particular geomorphologic, edaphic, and climatic conditions (Morgan 1982). Hence, the main aims of this study were: (1) to inventory the floristic composition of alder forests in El-Kala Biosphere Reserve and its surroundings, (2) to investigate the effect of abiotic factors (soil properties) on species richness and diversity, and (3) to distinguish plant communities based on species composition and to define spatial patterns of these plant communities.

\section{Materials and methods}

Study area. The El-Kala Biosphere Reserve (KBR hereafter) was created in 1983 by governmental decree no. 83-462 of July 23rd, and classified as Biosphere Reserve by UNESCO on December 17th, 1990. KBR is located at the extreme northeast region of Algeria, specifically in the northeast of Numidia area, between $36^{\circ} 56^{\prime} \mathrm{N}, 36^{\circ} 34^{\prime} \mathrm{N}$, and $8^{\circ} 12^{\prime} \mathrm{E}$, $8^{\circ} 41^{\prime} \mathrm{E}$ (Figure 1), and it has a surface of 76,438 ha. Elevation at KBR ranges from $100 \mathrm{~m}$ a.s.l. near the Oued El-Kebir river, to 1,202 $\mathrm{m}$ a.s.l. at Mount El-Ghorra. KBR is characterized by a Mediterranean climate, with dry hot summers followed by wet warm winters. According to climatic data for 2005-2015, the minimum mean monthly temperature is $10{ }^{\circ} \mathrm{C}$ in February, whereas the maximum mean is $25^{\circ} \mathrm{C}$ in July. Average total annual precipitation is $656 \mathrm{~mm}$, with four months having precipitation $<30 \mathrm{~mm}$ (WorldClim, 2.0; Fick \& Hijmans, 2017). Geology of KBR is characterized by two formations: the Quaternary, mainly represented by marine and river deposits, and the Miocene, including conglomerate sands and red clays, concentrated in the southeastern portion of the area (Joleaud 1936). Soils in the KBR are mainly brown washed with a variant of forest humus mull acidic Moder (Joleaud 1936).

Black alder forests of KBR have been widely altered by human activities (e.g., cutting, burning, draining and/or dumping); since that region is immediately close to the sea, those related to tourism and leisure prevail. Thus, being a region with an agricultural vocation, other activities contribute to the disturbance of these areas (i.e., the use of pesticides and the clearing of areas for agriculture).

Vegetation sampling. In order to investigate the floristic composition and spatial patterns of plant species assemblages in alder forests, surveys were conducted between 2016 and 2017 during the peak of vegetation development (spring and summer) (Ozenda 1982). During this time, 28 localities were sampled, which were representative of the three main substrates, i.e., fluvial ( $\mathrm{Fl})$, swampy ( $\mathrm{Sw})$, and sandy (Sa).

The relevé method developed by the Zürich-Montpellier school for field vegetation studies (Braun-Blanquet 1964) was applied, by using at least the minimum area recommended for these vegetation types $\left(16 \mathrm{~m}^{2}\right.$ for marshland vegetation, and $400 \mathrm{~m}^{2}$ for species-poor forests). We collected species when encountered for the first time or whenever there was uncertainty on their identity. Specimens were identified using Quézel \& Santa (1962).

The checklist of botanical families and species was organized alphabetically. Taxonomy and nomenclature follow the classification accepted by THE PLANT LIST database (The Plant List 2013), which is based on the APG III classification system for Angiosperms (APG III 2009). The updating and standardizing of species taxonomy and nomenclature according to APG III (2009) were guaranteed by 


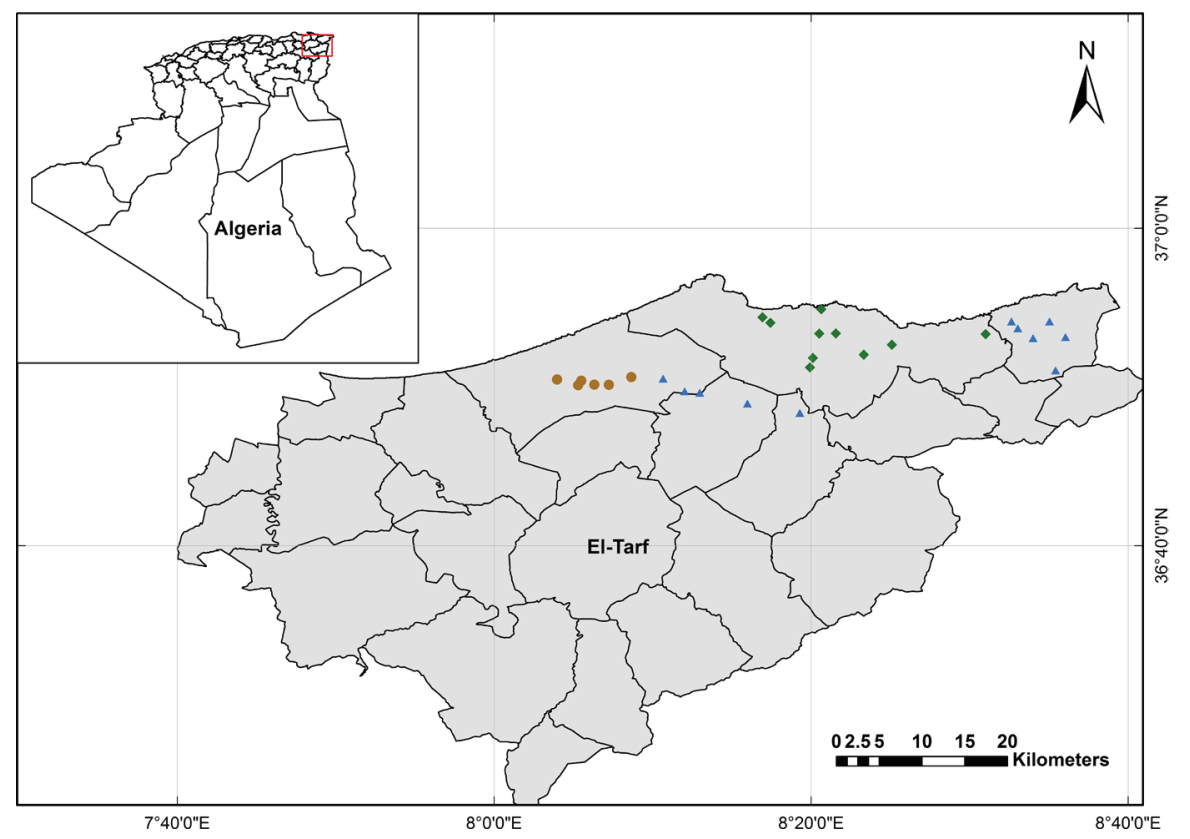

Figure 1. Map showing the location of El-Kala Biosphere Reserve (KBR) in northeastern Algeria (Projection system: GCS WGS 1984, coordinates in decimal degrees). Blue triangles indicate the exact location of fluvial sites (Fl), green polygones indicate swampy sites (Sw) and brown circles indicate sandy sites $(\mathrm{Sa})$.

using the Taxonomic Name Resolution Service v4.0 program (TNRS 2016). Species life forms were assigned based on Whittaker's (1975) classification system, a modified version of Raunkiaer's (1934) original classification scheme, which includes the following categories: helophytes (He), amphiphytes $(\mathrm{Am})$, phanerophytes $(\mathrm{Ph})$, hemicryptophytes (Hec), therophytes (Th), geophytes $(\mathrm{G})$, hydrophytes (Hy), chamaephytes $(\mathrm{Ch})$, and epiphytes (Ep).

Soil sampling. Soil samples were obtained with $5 \mathrm{~cm}$ diameter cores taken from three points at each site. The soil was sampled to a depth of $25 \mathrm{~cm}$. The three replicate samples were homogenized by hand mixing; large material (roots, stems, and pebbles) were hand-picked and discarded. Soil samples were air-dried and sieved with a $2 \mathrm{~mm}$ mesh for laboratory analyses. Soil analyses included determination of organic matter $(\mathrm{OM})$ using incineration method, and $\mathrm{pH}$ electrical conductivity (EC) based on a 1:5 soil-water solution using $\mathrm{pH} /$ conductivity meter. Next, Practical Salinity (PS) was obtained from EC, according to Fofonoff \&Millard (1983). In addition, total lime (TL) was determined using the titration method called 'calcimétrie de Bernard' (Fichaut 1989).

Data analyses. Plant diversity was evaluated using species richness (SR), defined as the total number of identified species (Magurran 2004). Further, percent relative richness (RR) was calculated for each family as the number of species contained in that family divided by the total number of species (SR). Occurrence frequency (Occ) was calculated for each species as the number of plots in which the species was recorded divided by the total number of sampled plots
(Magurran 2004). Bigot \& Bodot (1973) distinguished four species groups according to their occurrences: very accidental species (Vac), with occurrence $>12.5 \%$; accidental species (Acc), with occurrence varying between 12.5 and $24 \%$; common species $(\mathrm{Cmn})$, which occur in $25-49 \%$ of records; and constant species (Cst), which are present in 50 $\%$ or more of the samples.

Accumulation curves were drawn to evaluate sampling efficiency and to envisage if plant species from the three habitat types (Fl, Sw, Sa) were well represented and could be used for reasonable and significant assessments (Chao \& Chiu 2016). For all rarefaction/extrapolation (R/E) curves, we used 500 replicate bootstrapping runs to estimate $95 \%$ confidence intervals, using the "iNEXT" package (Hsieh et al. 2016) in $\mathrm{R}$ version 3.4.0 (R Core Team 2017). Accumulation curves were calculated using EstimateS software version 9.1.0 (Colwell 2013).

Soil parameters were compared among the three habitat types through linear mixed effects models (LMMs). Diagnostic quantile-quantile plots, used to examine the appropriateness of the models, revealed a good fit of the data to a normal distribution. Response variables were soil properties, habitat as taken as a fixed effect, whereas Season was declared as a random effect. We also used Tukey contrasts for LMMs for post-hoc comparisons of the different habitat types. These analyses were performed using the 'Imer' function of the lme4 package version 1.1-12 (Bates et al. 2015), and the 'glht' function of the multcomp package (Hothorn et al. 2013) in $\mathrm{R}$.

Multiple linear regression analyses were used to determine the signs of the relationships between species richness (SR) 


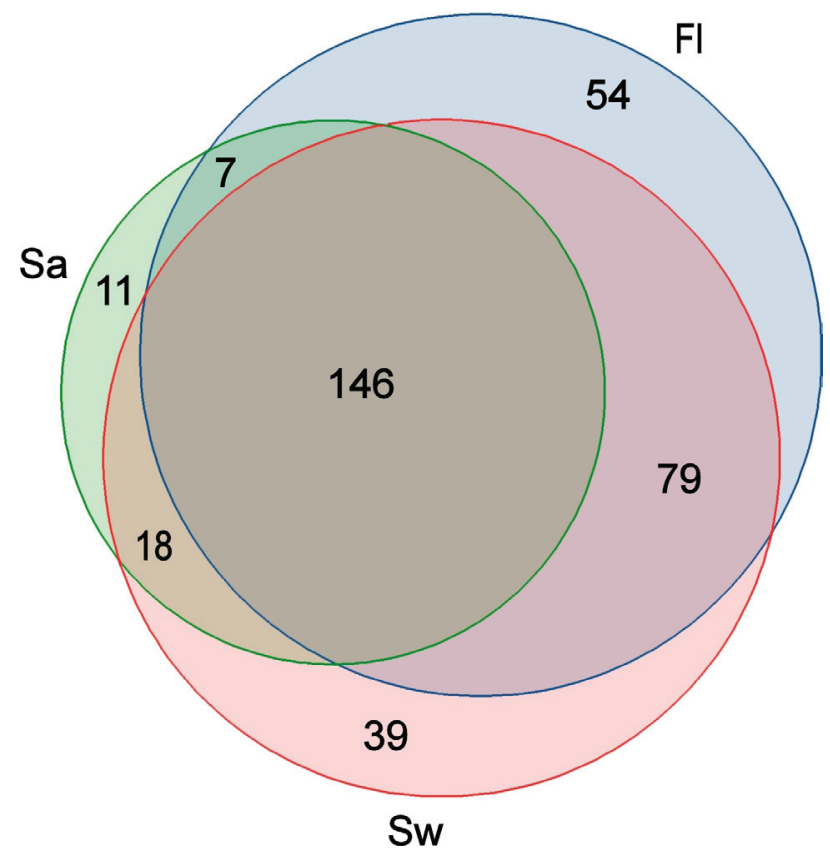

Figure 2. Venn diagram showing the distribution of species richness among the three habitat types. Each circle represents a habitat type (Fl, Fluvial; Sw, Swampy; Sa, Sandy).

and soil characteristics (OM, EC, pH, PS, TL). Analysis of variance for regression was used to assess significance (Kozak et al. 2008). Next, Non-metric Multidimensional Scaling (NMDS) was used to set up the spatial pattern in the scattergram. The ordination was fitted using the metaMDS function with Jaccard distances and two dimensions in the vegan package in R (Oksanen et al. 2017). Finally, to evaluate whether species were associated with particular habitats, and thus if they could be considered as indicators of such habitats, we performed an indicator value analysis (Dufrene \& Legendre 1997) using the "labdsv" package (Roberts 2016) in R. Taxa were considered good indicators if the indicator value was \pm 0.25 (Dufrene \& Legendre 1997).

\section{Results}

Floristic composition. In total, we identified 354 species belonging to 238 genera and 89 families (Appendix 1). Poaceae (35 species), Fabaceae (31), Cyperaceae (24), Asteraceae (24), Caryophyllaceae (13), Ranunculaceae (13), Lamiaceae (12), Brassicaceae (11), Juncaceae (11), Plantaginaceae (10), and Apiaceae (9) were the most species-rich families, accounting together for $54.51 \%$ of the total species richness. Fifty-four species were exclusive of fluvial sites ( $\mathrm{Fl}), 39$ of swampy sites (Sw), and 11 species of sandy sites ( $\mathrm{Sa}$ ); Fl and $\mathrm{Sw}$ shared 79 species, $\mathrm{Sa}$ and $\mathrm{Sw}$ shared 18 species, whilst $\mathrm{Sa}$ and Fl shared only seven species (Figure 2). Notably, 146 species occurred in all three habitat types.

Overall, the most species-rich genera were Carex (11 species), Juncus (10), Ranunculus (10), Trifolium (9), Vicia (5), Cyperus (4), Euphorbia (4), Plantago (4), Persicaria (4) and Silene (4), accounting together for $18.36 \%$ of all species. Amongst the inventoried species only 13 (3\%) were endemic to North Africa, and two species were endemic to the study region (Hypericum afrum (Desf.) Lam. and Solenopsis laurentia (L.) C. Presl.).

Life form distribution. Therophytes were the most common life form (127 species, $35.88 \%$ ), while 98 species (27.68\%) were Hemicryptophytes, 52 (14.69\%) Phanerophytes, 20 (5.65\%) Geophytes, 19 (5.37\%) Helophytes, 17 (4.80\%) Hydrophytes, 11 (3.11\%) Chamaephytes, and 8 (2.26\%) were Amphiphytes (Figure 3). Bryophytes and Epiphytes were represented by one species only.

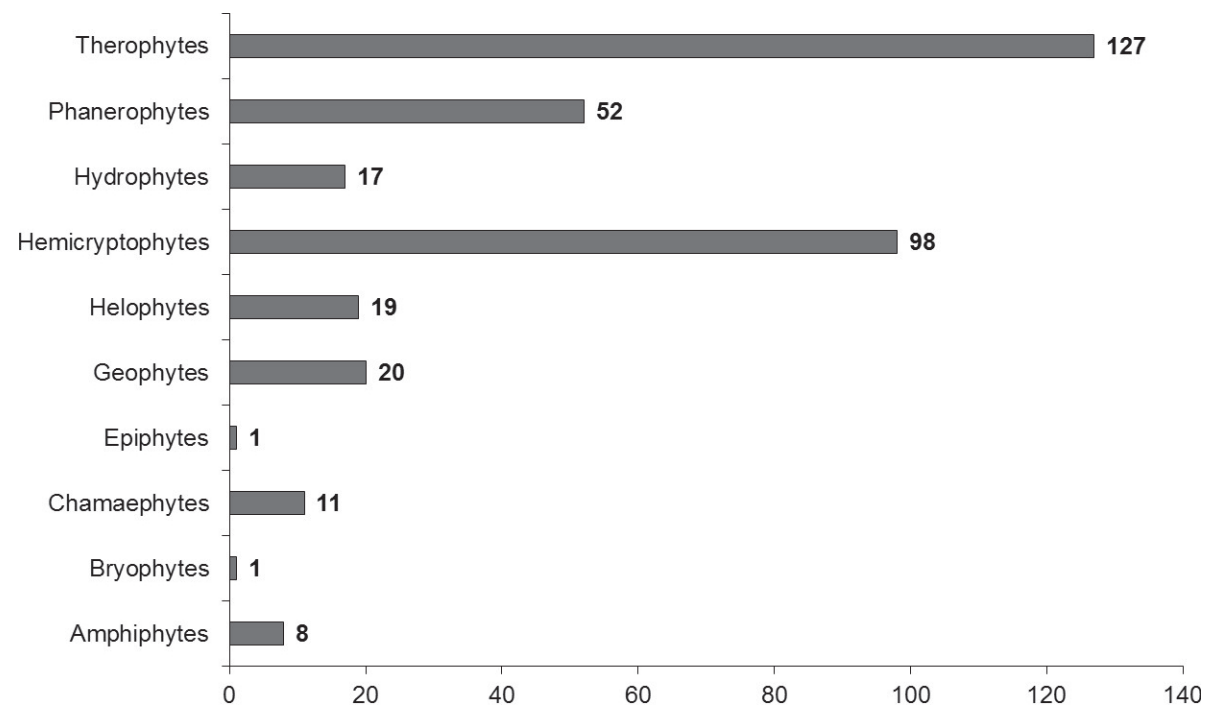

Figure 3. Life form frequency distribution in the flora recorded in the El-Kala Biosphere Reserve, norteastern Algeria. 
Diversity and similarity. Species rarefaction curves revealed that the mean observed species richness was highest in fluvial and swampy sites, in contrast with sandy sites (Figure 4a), with 285, 282 and 182 species, respectively (Table 1). There was a strong overlap between fluvial and swampy sites, whilst sandy sites stood out for not having any floristic overlap with the other habitat types (Figure 4A, Table 1).

Figures $4 \mathrm{~B}$ and $4 \mathrm{C}$ show that only four sampling units were necessary to reach $80 \%$ of the estimated species richness for the sandy and swampy habitats, while five were required for the fluvial one.

The ordination based on species presence/absence achieved a stable two dimension solution (stress $=0.154$ ) and enabled us to plot different habitats in a two-dimensional space (Figure 5). Sandy sites were quite homogeneous, concentrated together and visibly separated from the other habitats. Swampy sites were separated from the other habitats with high heterogeneity and some level of overlapping with the fluvial ones. Finally, fluvial sites were instead poorly clustered and scattered among the others (Figure 5).

Relation of diversity to environmental factors. Variation in soil properties among the three habitat types was tested using Tukey contrasts for linear mixed models (LMMs). Soil $\mathrm{pH}$ differed significantly among habitat types $\left(\chi^{2}=9.9941\right.$; $\mathrm{df}=2 ; P=0.006)$. Tukey tests revealed that soil $\mathrm{pH}$ differs significantly between swampy and fluvial sites, on one hand, and between swampy and sandy sites, on the other (Figure $6 \mathrm{~A}$ ). Soil organic matter (MO) was highly different among the three habitat types $\left(\chi^{2}=2498.4\right.$; df $\left.=2 ; P<0.001\right)$. Posthoc analysis showed that OM was highly different among the three habitat types (Fl-Sw, Sw-Sa, Fl-Sa; Figure 6B), in contrast with the other soil parameters, which showed homogeneity among habitats.
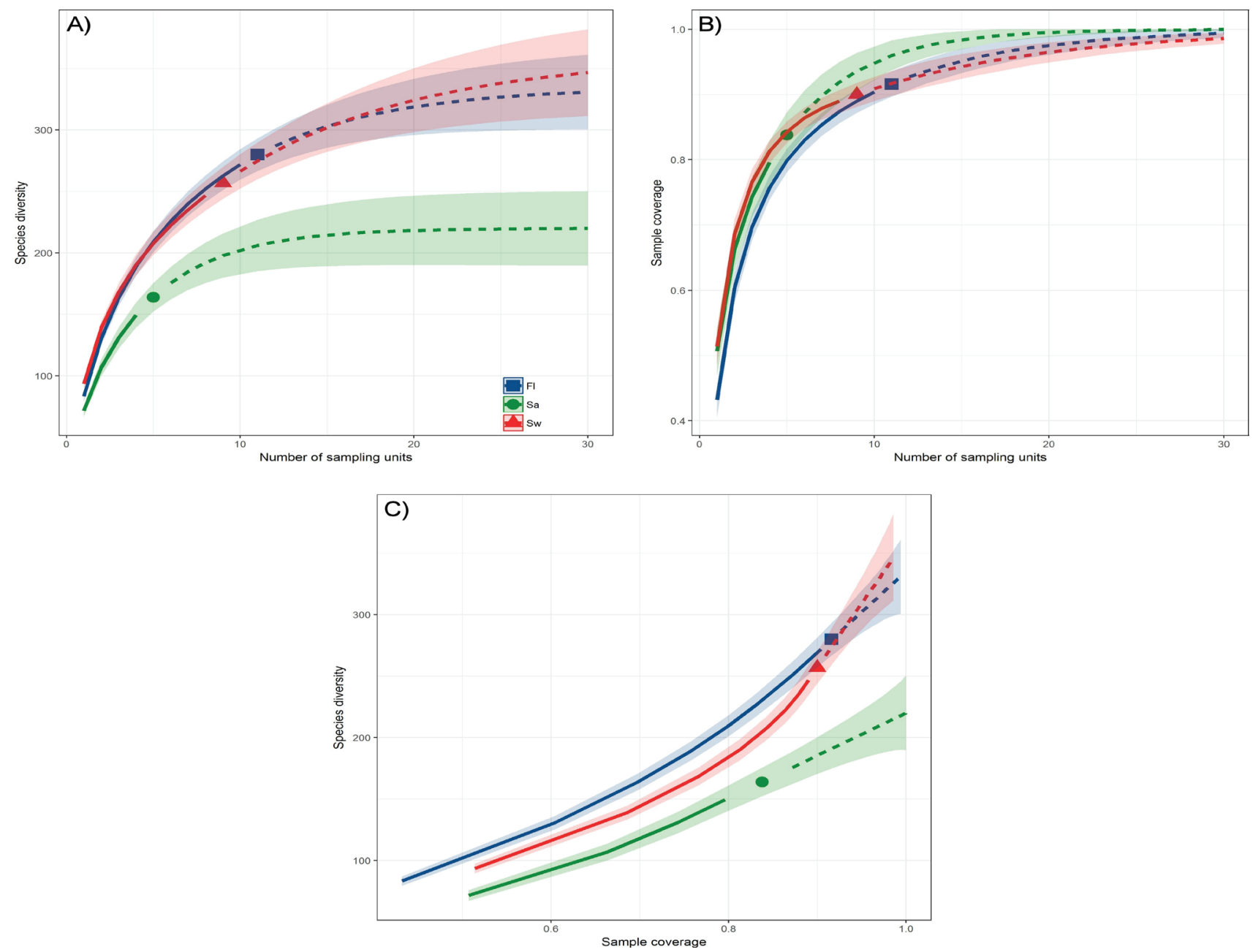

Figure 4. A. Sample-based rarefaction and extrapolation for plant species richness. B. Sample coverage as a function of sample size. C. Coverage-based rarefaction and extrapolation for plant species richness. Number of sampling units indicates the cumulative number of plots. Continuous and discontinuous lines in all panels represent rarefaction and extrapolation, respectively; the shaded areas represent the $95 \%$ confidence interval. Fl, Fluvial sites; Sw, Swampy sites; Sa, Sandy sites. 
Table 1. Summary of plant diversity at each habitat type $(\mathrm{Fl}=$ Fluvial; $\mathrm{Sw}=\mathrm{Swampy} ; \mathrm{Sa}=\mathrm{Sandy}, \mathrm{CI}=\mathrm{Confidence}$ interval, $\mathrm{SD}=\mathrm{Standard}$ deviation).

\begin{tabular}{lccc}
\hline & Fl & Sw & Sa \\
\hline S(est) Mean \pm SD & $285 \pm 5.85$ & $282 \pm 8.94$ & $182 \pm 7.59$ \\
$95 \%$ CI Lower Bound & 273.54 & 264.48 & 167.12 \\
$95 \%$ CI Upper Bound & 296.46 & 299.52 & 196.88 \\
Chao 2 Mean \pm SD & $323.82 \pm 11.77$ & $393.47 \pm 29.91$ & $266.42 \pm 25.25$ \\
$95 \%$ CI Lower Bound & 306.7 & 348.48 & 229.57 \\
$95 \%$ CI Upper Bound & 354.44 & 468.9 & 331.84 \\
Jack 1 Mean \pm SD & $355.58 \pm 18.59$ & $373.8 \pm 19.75$ & $251.17 \pm 8.11$ \\
Jack 2 Mean & 366.72 & 425.53 & 288.37 \\
Bootstrap Mean & 321.07 & 323.05 & 213.18 \\
\hline
\end{tabular}

Multiple linear regression analyses showed no linear relationships between species richness and soil parameters, except for OM $(P=0.013)$ (Table 2$)$. ANOVA results confirmed this results, as significant variation in species richness was observed in relation to $\mathrm{OM}$, but not with the four other parameters, namely $\mathrm{pH}, \mathrm{TL}, \mathrm{EC}$, and PS (Table 3 ).

Indicator species analysis. Ten plant species were highly (indicator value $>0.25)$ and significantly $(P<0.05)$ indica- tive of the three habitat types in the total dataset (Table 4). Among them, five were indicators of swampy sites, three more were indicators of the sandy habitat, and only two species were indicators of fluvial sites.

\section{Discussion}

Through this investigation, we were able to produce a substantial checklist of the vascular flora occurring in alder forests of

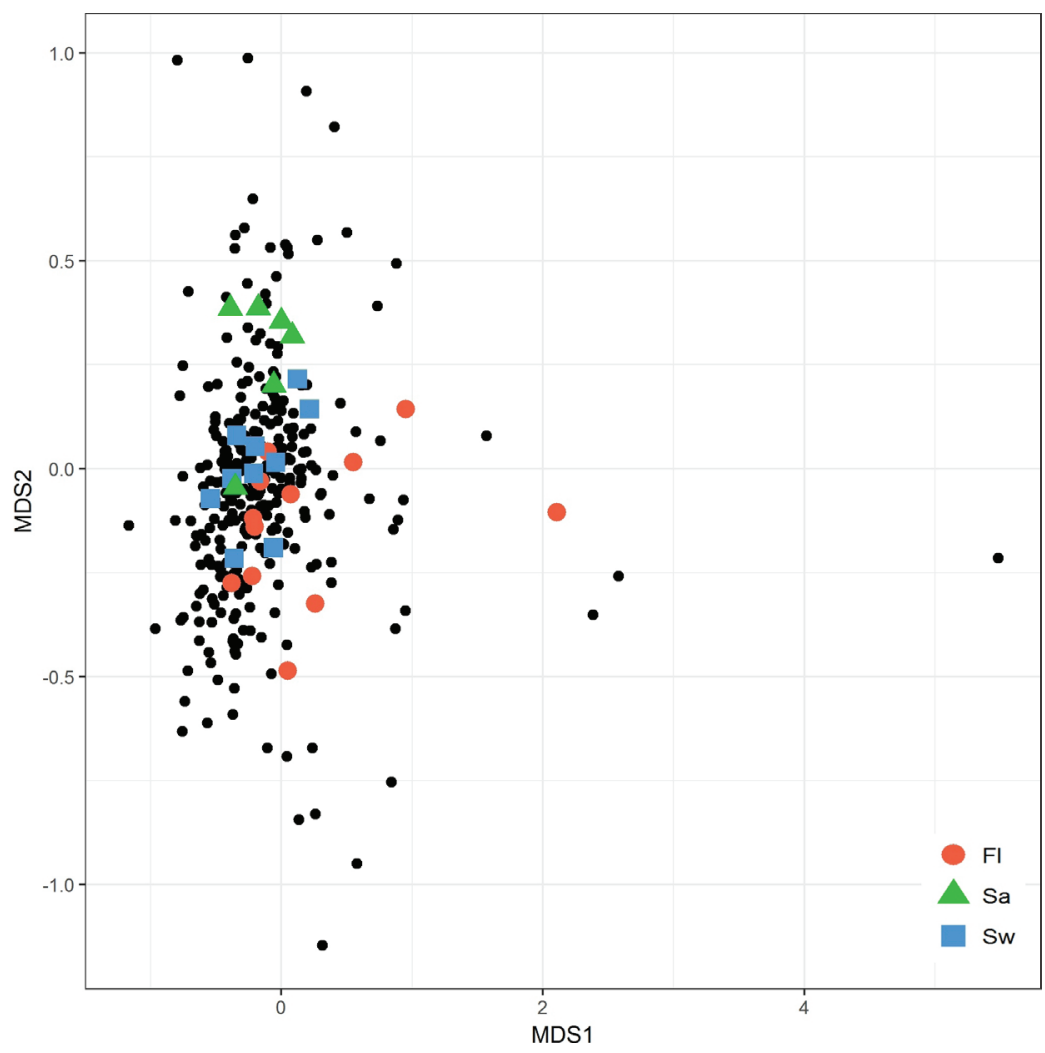

Figure 5. Non-metric multidimensional scaling ordination (NMDS) biplot of habitat (color figures) and species (black dots). Fl, Fluvial sites; Sw, Swampy sites; Sa, Sandy sites. 

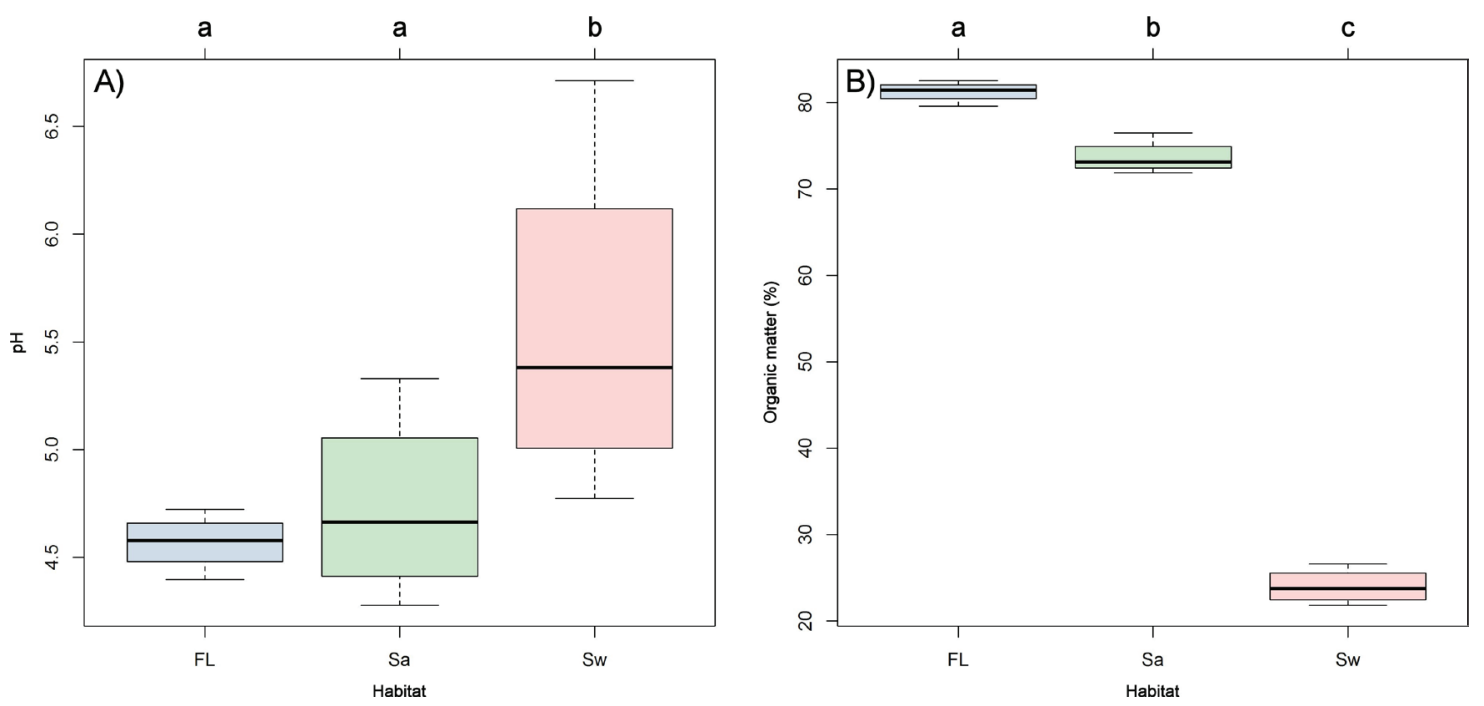

Figure 6. A. Box-plots of variation in $\mathrm{pH}$ and B. Organic matter $( \pm 95 \% \mathrm{CI})$ in the three sampled habitats. The letters indicate the statistical groupings (Tukey's post-hoc tests); box-plots with the same letter are not significantly different.

KBR. This checklist contributes to our understanding of those species that can thrive in these forest type, which characteristically become flooded for a long time every year, thus representing one of the exceptional wetlands in North Africa.

According to Quézel (1978), the most diverse families represented in the Mediterranean North African flora are Poaceae, Fabaceae, Cyperaceae, Asteraceae, Juncaceae, Ranunculaceae, and Brassicaceae, and our results agree with this statement. However, a noticeable discrepancy arises when comparing our study with that of Ghahreman et al. (2006), conducted in the northeastern Mediterranean region (Caspian lowlands), in which they report Rosaceae, Papilionaceae, Asteraceae, Cyperaceae, Brassicaceae, Lamiaceae, Scrophulariaceae, Apiaceae, Ranunculaceae, Aspidiaceae, Polygonaceae, and Liliaceae as the families having the largest species richness. Moreover, in terms of genera our results also differ from those reported by the same study, in which Asteraceae (11 genera), Poaceae (10 genera), Rosaceae (9 genera), Lamiaceae (8 genera), Apiaceae (5 genera) and Liliaceae ( 5 genera) were reported to be the best-represented families, and Carex (9 species), Rubus (6), Cardamine (5), Ranunculus (5), Veronica (5), Polystichum (4), Dryopteris (3), Equisetum (3), Geranium (3), Poa (3), and Solanum (3) were listed as the most speciose genera in alder forests. In turn, Bensettiti (1995) stated that the high abundance of Poaceae and Cyperaceae in alder forests reflects the degradation of some parts of these habitats into marshy prairies.

The life form spectrum of the KBR flora, dominated by therophytes, characteristically reflects the influence of the Mediterranean bioclimate (Medjahdi et al. 2009). Raunkiaer (1934) defined the Mediterranean climate type as a 'therophyte climate' (as therophytes are plants that remain in the soil as seeds during a certain period, whereas the vegetative parts are annual). This definition is based on the fact that all species with this life form account for over $50 \%$ of the Mediterranean flora (Raven 1971). This proposition of Raunkiaer was confirmed by Cain (1950) in California, and by Quézel (1978) in North Africa. Nonetheless, this generalization was refuted in Chile, the Cape Region of South Africa and South Western Australia, where therophytes are normally absent and only appear in the immediate post-fire periods or after abundant rains (Blondel \& Aronson 1995). In northeastern Mediterranean alder forests (Caspian lowlands), Ghahreman et al. (2006) found that geophytes were the dominant life form, accounting for $30 \%$ of studied flora, followed by phanerophytes $(22 \%)$, therophytes $(21 \%)$, hemicryptophytes

Table 2. Multiple linear regression models used to test the dependence of diversity variables on environmental variables.

\begin{tabular}{llccccc}
\hline Diversity measure & Independent variables & Estimate & SE & $\boldsymbol{t}$ & $\boldsymbol{R}_{\text {adj }}$ \\
\hline & EC & $-17,577.715$ & $21,592.463$ & 0.424 & 0.08 & 0.180 \\
& pH & -571.11 & 299.307 & 0.069 & \\
Species richness & TL & -134.385 & 166.441 & 0.428 & \\
& MO & -13.462 & 5.021 & 0.013 & \\
& PS & $43,944.74$ & $48,410.323$ & 0.373 & \\
\hline
\end{tabular}


Table 3. ANOVA results of the multiple linear regression

\begin{tabular}{llcccccc}
\hline Diversity measure & Independent variables & Mean \pm SE & df & Sum sq & Mean sq & $\boldsymbol{F}$ & \multicolumn{1}{c}{$\boldsymbol{P}$} \\
\hline & EC & $0.491 \pm 0.006$ & 1 & 170 & 169.9 & 0.049 & 0.826 \\
& pH & $4.95 \pm 0.088$ & 1 & 12,761 & $12,760.8$ & 3.697 & 0.067 \\
Species richness & TL & $2.568 \pm 0.072$ & 1 & 35 & 34.9 & 0.010 & 0.920 \\
& MO & $59.187 \pm 5.083$ & 1 & 23,145 & $23,144.9$ & 6.705 & 0.016 \\
& PS & $0.214 \pm 0.003$ & 1 & 2,844 & $2,844.4$ & 0.824 & 0.373 \\
\hline
\end{tabular}

(17\%), hydrophytes (9\%), and chamaephytes (1\%). Usually, the high incidence of therophytes in plant communities is a result of increasing aridity (Barbero et al. 1989), and as in the present study, therophytes were the most common life form; their ample presence can be attributed to the habitats characterized by seasonal immersion/flooding, which are favorable to the development of annual plants capable of germinating and growing faster under harsh conditions (Hammada et al. 2004). Therefore, and due to their low ecological requirements, therophytes inhabit numerous habitats types (Gomaa 2012). In addition, the therophyte life form represents the eventual phase of degradation in xeric habitats, as it is frequently linked to environmental perturbations by grazing (Quézel 2000). The high rate of hemicryptophytes in all habitats is typical for pasture flora (Vitasović-Kosić $\&$ Britvec 2007). In turn, the low percentage of chamaephytes in alder forests reflects the low light intensity in the understory and the occurrence of long flood periods in these habitats (Thomas 1975).

According to the NMDS results, we were able to classify our study sites into two major groups, namely the marshy and the hilly (swampy-sandy) black alder forests, and the fluvial forests, in relation to plant species richness. This result is not surprising since Thomas (1975) had already shown that this dichotomy is the result of differences in the

Table 4. Plant species with a significant indicator value at El-Kala Biosphere Reserve, northeastern Algeria. Habitat type abbreviations as in Table 2.

\begin{tabular}{lccc}
\hline Species & Habitat type & Indicator value & $\boldsymbol{P}$ \\
\hline Stellaria media & $\mathrm{Fl}$ & 0.416 & 0.009 \\
Rosa sempervirens & $\mathrm{Fl}$ & 0.416 & 0.014 \\
Cotula coronopifolia & $\mathrm{Sw}$ & 0.578 & 0.007 \\
Genista ferox & $\mathrm{Sw}$ & 0.469 & 0.013 \\
Anthoxanthum odoratum & $\mathrm{Sw}$ & 0.423 & 0.023 \\
Fumaria capreolata & $\mathrm{Sw}$ & 0.375 & 0.047 \\
Clematis cirrhosa & $\mathrm{Sw}$ & 0.300 & 0.043 \\
Vicia narbonensis & $\mathrm{Sa}$ & 0.476 & 0.017 \\
Dipsacus fullonum & $\mathrm{Sa}$ & 0.416 & 0.020 \\
Raphanus raphanistrum & $\mathrm{Sa}$ & 0.365 & 0.048 \\
\hline
\end{tabular}

length of the flood period (seven to twelve months for hilly and marshy forests, whilst inundation only occurs during the flood season in fluvial alder forests), water level and light intensity. The spatial arrangement of the vegetation in this type of wetlands is not accidental; rather, it is the result of the interaction of numerous ecological factors, including abiotic, biotic, or anthropogenic (Alvarez-Rogel et al. 2007, Minggagud \& Yang 2013).

Soil supply levels are important variables for plant diversity and community structure. Some features of plant community organization, such as composition and diversity of plant functional types, also affect plant productivity, maintenance, and soil fertility (Tilman et al. 1996). Soil pH is a relevant factor for plant development; it affects nutrient availability, toxicity, and microbial activity, and it exerts a direct effect on the protoplasm of plant root cells (Larcher 1980, Marschner 1986). Gould \& Walker (1999) found a correlation between plant richness and $\mathrm{pH}$; in their model, species richness declined when soil $\mathrm{pH}$ was at its acidic and alkaline extremes, which may be related to the nutrient availability and toxicity. In acidic soils, $\mathrm{Al} 3+, \mathrm{Cu} 2+, \mathrm{Fe} 3+, \mathrm{Mn} 2+$ ions increase to toxic levels for the bulk of plant species (Wolf 2000). Alkaline soils $(\mathrm{pH}>8$ ) have a tendency to be poor in $\mathrm{Zn}, \mathrm{Fe}, \mathrm{Cu}, \mathrm{K}$ and $\mathrm{Mn}$ (Marschner 1986). Different plant species may not be as adaptable and thus they could need a narrow range of $\mathrm{pH}$ to live (Leskiw 1998). There is evidence that forest soils must be somewhat acidic for the nutrient resource to be stable (Leskiw 1998); yet, this does not seem to be the case in the present study, as no significant relationship was found between soil $\mathrm{pH}$ and richness.

Our study revealed a significant effect of soil organic matter on species richness. Soil organic matter contributes to soil fertility by providing nutrients and increasing both cation exchange and water holding capacity (Brady \& Weil 1999). Few species can tolerate nutrient deficiency (Austin 2002). As resource availability increases, more species can persist and henceforth species richness increases.

The study of the vegetation of black alder forests in KBR allowed us to produce a more complete inventory of the plant community, and to better understand the distribution of vegetation across the area, as well as to identify those factors that affect its zonation. For this ecosystem, our study revealed a vegetation of relatively high diversity that is related to the variation of soil parameters. Black alder forests of KBR are predominantly disturbed by human activities, especially 
those related to tourism and leisure (e.g., cutting, burning, draining and/or dumping), which explains the degradation state of the ecosystem. Hence, more conservation efforts focused on these habitats should be made, supplemented with quantitative studies, in order to reduce anthropic activities and their impacts on the El-Kala Biosphere Reserve.

\section{Acknowledgements}

We would like to thank the team of the Laboratory of Functional and Evolutionary Ecology, University of Chadli Bendjedid (El Tarf, Algeria), for their support in specimen processing. We also thank Professor Jorge A. Meave (Plant Ecology and Diversity Group, UNAM), for its helpful comments on the manuscript. We also thank two anonymous referees for the English edition review. Authors also thank Dr. Idriss Bouam for his assistance in statistical analyses. This research received no specific grant from any funding agency.

\section{Literature cited}

Álvarez-Rogel J, Jiménez-Cárceles FJ, Roca MJ, Ortiz R. 2007. Changes in soils and vegetation in a Mediterranean coastal salt marsh impacted by human activities. Estuarine Coastal and Shelf Science 73: 510-526.

DOI: http://doi.org/10.1016/j.ecss.2007.02.018

APG III [Angiosperm Phylogeny Group III]. 2009. An update of the Angiosperm Phylogeny Group classification for the orders and families of flowering plants: APG III. Botanical Journal of the Linnean Society 161: 105-121.

DOI: http://doi.org/10.1111/j.1095-8339.2009.00996.x

Austin MP. 2002. Spatial prediction of species distribution: an interface between ecological theory and statistical modelling. Ecological Modelling 157: 101-118. DOI: http://doi.org/10.1016/S0304-3800(02)00205-3

Barbero M, Bonin G, Loisel R, Quéezel P. 1989. Sclerophyllous Quercus forests of the Mediterranean area: Ecological and ethological significance. Bielefelder Ökologische Beiträge 4: 1-23.

Bates D, Maechler M, Bolker B, Walker S. 2015. Fitting linear mixed-effects models using lme4. Journal of Statistical Software 67: 1-48. DOI: http://doi.org/10.18637/jss.v067.i01

Belouahem D, Belouahem F, Benslama M, Bélair G, Muller SD. 2011. Alder forests of Numidia (N.E. Algeria): Floristic biodiversity, vulnerability and conservation. Compte Rendues Biologies 334: 61-73.

DOI: http://doi.org/10.1016/j.crvi.2010.10.005

Bensettiti F, Lacoste A. 1999. Les ripisylves du Nord de l'Algérie Essai de synthèse synsystématique à l'echelle de la Méditerranée occidentale. Ecologia Mediterranea 25: 13-39. available online in: <https://ecologia-mediterranea.univ-avignon.fr/ wp-content/uploads/sites/25/2017/07/Ecologia_mediterranea 1999-25_1_01.pdf> (Accessed: July 2016).

Bensettiti F. 1995. Contribution à l'étude phytosociologique des ripisylves du Nord de l'Algérie. Essai de synthèse à l'échelle de la Méditerranée occidentale. PhD.Thesis Univ. de Paris-Sud Centre Orsay.
Bensimon C. 1985. Male sterility in Alnus glutinosa (L.) Gaertn. Silvae Genetica. 34: 69-72.

Bigot L, Bodot P. 1973. Contribution à l'étude biocénotique de la garrigue à Quercus coccifera - Composition biotique du peuplement des invertébrés. Vie et Milieu 23: 229-249.

Blondel J, Aronson J. 1995. Biodiversity and ecosystem function in the Mediterranean basin. In: Davis GW, Richardson DM. (eds.). Human and non-human determinants in Mediterranean type ecosystems. The function of biodiversity. Berlin: Springer-Verlag, 45-119. DOI: http://doi.org/10.1007/978-3-642-78881-9_2

Brady NC, Weil RR. 1999. The Nature and Properties of Soils. London: Prentice Hall Publishers. ISBN-13: 978-0133254488.

Braun-Blanquet J. 1964. Pflanzensoziologie. 3. Aufl. Wien-New York: Springer Verlag.

Cain SA. 1950. Life-forms and phytoclimate. Botanical Review 16: $1-32$.

Claessens H. 2003. The alder populations of Europe. Forestry Commission Bulletin. 126: 5-14.

Colwell R. 2013. EstimateS: Statistical estimation of species richness and shared species from samples. Version 9.1.0. Available at $<$ http://purl.oclc.org/estimates $>$ (Accessed: July 2016).

Dufrene M, Legendre P. 1997. Species assemblages and indicator species, the needs for a flexible asymmetrical approach. Ecological Monographs. 67: 345-366.

DOI: http://doi.org/10.1890/0012-9615(1997)067\%5b0345: SAAIST $\% 5 \mathrm{~d} 2.0 . \mathrm{CO} ; 2$

Dussart G. 1999. The ecological implications of loss of alder trees. Consolidates Progress Report of the EU Concerted Action, FAIR5-CT97-3615.

Fichaut B. 1989. Morphosédimentologie de la partie occidentale de la rade de Brest. Norois 144. 377-390

Fick, S.E. and R.J. Hijmans, 2017. Worldclim 2: New 1-km spatial resolution climate surfaces for global land areas. International Journal of Climatology. WorldClim 1.4 (current conditions) by <www.worldclim.org $>$ (Accessed: July 2016).

Fofonoff NP, Millard RC. 1983. Algorithms for Computation of Fundamental Properties of Seawater. Technical Papers in Marine Science (UNESCO) 44: 53

Géhu JM, Kâabeche RM. Gharzouli. 1994. L'aulnaie glutineuse de la région d'El Kala (la Calle), Annaba, Algérie: une remarquable irradiation biogéographique européenne en Afrique du Nord. Fitosociologia 27: 67-71.

Ghahraeman A, Naqinezhad AR, Hamzeh'ee B, Attar F, Assadi M. 2006. The flora of threatened black alder forests in the Caspian lowlands, northern Iran. Rostaniha 7: 5-30.

Gomaa NH. 2012. Composition and diversity of weed communities in Al-Jouf province, northern Saudi Arabia. Saudi Journal of Biological Sciences 19: 369-376. DOI: http://doi.org/10.1016/j.sjbs.2012.05.002

Gould WA, Walker MD. 1999. Plant communities and landscape diversity along a Canadian Arctic river. Journal of Vegetation Science 10: 537-548. DOI: http://doi.org/10.2307/3237188

Hammada S, Dakki M, Tattou MI, Ouyahya S, Fennane M. 2004. Analyse de la biodiversité floristique des zones humides du Maroc - Flore rare, menacée et halophile. Acta Botanica Malacitana 29: 43-66. 
Hothorn T, Bretz F, Westfall P, Heiberger RM \& Schuetzenmeister A. 2013. Simultaneous Inference in General Parametric Models. R Package Version 1.3- 1. <http://cran.r-project. org/web/packages/multcomp> (Accessed: July 2016).

Hsieh TC, Ma KH, Chao A. 2016. iNEXT: an R package for rarefaction interpolation and extrapolation for species diversity (Hill numbers). Methods in Ecology and Evolution. 7: 1451-1456. DOI: http://doi.org/10.1111/2041-210X.12613

Jalas J. Suominen J. 1976. Atlas Florae Europaeae; 3: Salicaceae to Balanophoraceae. Helsinki. ISBN: 951-9108-02-5.

Joleaud L. 1936. Etude géologique de la région de Bône et de la Calle. Bulletin du service de la Carte géologique d'Algérie Imp. Algiers.

Kajba D. Gracan J. 2003. EUFORGEN Technical Guidelines for genetic conservation and use for Black Alder (Alnus glutin$o s a$ ). Rome: International Plant Genetic Resources Institute.

Kozak A, Kozak R A, Staudhammer CL, Watts SB. 2008. Introductory Probability \& Statistics: Applications for Forestry \& the Natural Sciences. Cambridge, UK: Cambridge University Press. ISBN-13: 978-1780640518

Larcher W. 1980. Physiological Plant Ecology. NewYork: Springer-Verlag. ISBN 978-3-540-43516-7

Leskiw LA. 1998. Land capability classification for forest ecosystems in the oil sands region. Alberta: Cumulative environmental Management Association. Fort McMurray.

Magurran AE. 2004. Measuring biological diversity. Oxford: Wiley-Blackwell. ISBN: 9780632056330

Marschner H. 1986. Mineral nutrition of higher plants. London: Academic Press. ISBN 9780124735408

Medjahdi B, Tattou MI, Barkat D, Benabdelli K. 2009. La flore vasculaire des monts de Trara (Nord-Ouest algérien). Acta Botanica Malacitana 34: 57-75.

Minggagud H, Yang J. 2013. Wetland plant species diversity in sandy land of a semi-arid inland region of China. Plant Biosystems 147: 25-32.

DOI: http://doi.org/10.1080/11263504.2012.737865

Morgan NC. 1982. An ecological survey of standing waters in North West Africa: II. Site descriptions of Tunisia and Algeria. Biological Conservation 24: 83-113.

DOI: http://doi.org/10.1016/0006-3207(82)90062-3

Oksanen J, Blanchet FG, Friendly M, Kindt R, Legendre P, McGlinn D, Minchin PR, O'Hara RB, Simpson GL, Solymos P, Stevens MHH, Szoecs E, Wagner H. 2017. vegan: community ecology package. R package version 2.4-3. Available at: https://cran.r-project.org/web/packages/vegan/index.html

Ozenda P. 1982. Les végétaux dans la biosphère. Paris: Doin. ISBN-13: 978-2704003990

Piégay H, Pautou G, Ruffioni C. 2003. Les forêts riveraines des cours d'eau. Ecologie, fonctions et gestion. Paris: Institut pour le développement forestier.

Pinay G, Labroue L. 1986. Une station d'épuration naturelle des

Associated editor: Salvador Arias

Author Contributions: AT conceived the ideas, designed the methodology and reviewed the draft; AN led the writing for the manuscript, carried out fieldwork and analyzed the data; DB-A and MS helped in fieldwork. All authors contributed critically to the drafts and gave final approval for publications. nitrates transportés par les nappes alluviales: l'aulnaie glutineuse. Paris: Comptes rendus de l'Académie des Sciences.

Quézel P. 2000. Réflexions sur l'évolution de la flore et de la végétation au Maghreb méditerranéen. Paris: Ibis Press.

Quézel P, Santa S. 1962. Nouvelle Flore de l'Algérie et des régions méridionales I, II. Paris : CNRS.

Quézel P. 1978. Analysis of the flora of Mediterranean and Saharan Africa. Annals of the Missouri Botanical Garden 65: 479-534. DOI: http://doi.org/10.2307/2398860

R Core Team. 2017. R: A language and environment for statistical computing. $R$ Foundation for Statistical Computing $<$ https://cran.r-project.org $>$

Raunkiaer CC, Fausbøll AI, Gilvert-Carter H, Tansley AG. 1934. The life forms of plants and statistical plant geography. being the collected papers of C. Raunkiaer Oxford: Claredon press.

Raven P. 1971. Relationships between Mediterranean floras. In: Davis PH, Harper PC, Hedge IC. (eds.). Plant life in southwest Asia. Edinburgh: Botanical Society of Edinburgh.

Roberts DW. 2016. labdsv: ordination and multivariate analysis for ecology. R package version 1.8-0. <http://ecology.msu. montana.edu/labdsv/R/> (Accessed: July 2016).

Schnitzler-Lenoble, A, Carbiener R. 1993. Les forêts galeries d'Europe. La Recherche 255: 694-700.

Shaw K, Roy S, Wilson B. 2014. Alnus glutinosa, common Alder In: The IUCN Red List of Threatened Species 2014: e.T63517A3125479.

DOI: http://doi.org/10.2305/IUCN.UK.2014-3.RLTS. T63517A3125479.en.

The Plant List. 2013. The Plant List. A working list of all plant species. Version 1.1. <http://www.theplantlist.org/> (Accessed: July 2016).

Thomas JP. 1975. Ecologie et dynamisme de la végétation des dunes littorales et des terrasses sableuses quaternaires de Jijel à El Kala (Est algérien). BSc. Thesis. Montpellier.Université des Sciences et Techniques de Montpellier.

Tilman D, Wedin D, Knops J. 1996. Productivity and sustainability influenced by biodiversity in grassland ecosystems. $\mathrm{Na}$ ture. 379: 718-720. DOI: http://doi.org/10.1038/379718a0

TNRS [Taxonomic Name Resolution Service]. 2016. Taxonomic Name Resolution Service V. 4.0. iPlant collaborative. $<$ http:// tnrs.iplantcollaborative.org> (accessed August, 2014).

Vitasović-Kosić I, Britvec M. 2007. Plant Diversity of Pastures on the Family Farms in the Southern Part of Istria (Croatia). Agriculturae Conspectus Scientificus. 72: 141-147.

Whittaker RH. 1975. Communities and ecosystems. New York: MacMillan. ISBN-13: 978-0024273901

Wolf B. 2000. The fertile triangle. The interrelationship of air, water, and nutrients in maximizing soil productivity. New York: Food Products Press. ISBN-13: 978-1560228783 
Appendix 1. Systematic list of plant species inventoried in the El-Kala Biosphere Reserve (northeastern Algeria), along with their life form, frequency of occurrence (Occ) and scale of occurrence (Occ scale) (Acc: Accidental, Cmn: Common, Cst: Constant, Vac: very accidental). Life forms: He, Helophyte; Am, Amphiphyte; Ph, Phanerophyte; Hec, Hemicryptophyte; Th, Therophyte; G, Geophyte; Hy, Hydrophyte; Ch, Chamaephyte; Ep, Epiphyte.

\begin{tabular}{l} 
Family (RA \%) \\
Species \\
\hline
\end{tabular}

Acanthaceae (0.28)

Acanthus mollis L.

$\mathrm{He}$

Occ Occ

(\%)

scale

\section{Alismataceae (0.56)}

Alisma plantago-aquatica L.

$\begin{array}{lll}\text { Am } & 75 & \text { Cst } \\ \text { Am } & 10.7 & \text { Vac }\end{array}$

Baldellia ranunculoides Parl.

Am

$\mathrm{He}$

78.6

Cst

Allium triquetrum $L$.

Cmn

Alternanthera sessilis (L.) DC.

$\mathrm{Am}$

7.1

$\mathrm{Vac}$

\section{Anacardiaceae (0.28)}

Pistacia lentiscus L.

$\mathrm{Ph}$

Cmn

Apiaceae (2.54)

Apium crassipes Rchb.f.

Acc

Apium nodiflorum (L.) Lag.

Am

78.6

Cst

Daucus carota L. subsp. maritimus Batt.

$\mathrm{Hec}$

$28.6 \quad \mathrm{Cmn}$

Daucus carota L. subsp. maximus (Desf.) Ball.

$\mathrm{He}$

60.7

Cst

Daucus virgatus (Poir.) Maire

$\mathrm{Hec}$

$17.9 \quad$ Acc

Eryngium barrelieri Boiss.

Oenanthe globulosa L.

$\mathrm{He}$

Hc

Torilis arvensis (Huds) Link.

$\mathrm{Th}$

Torilis nodosa (L.) Gaertn.

Th

Apocynaceae (0.28)

Nerium oleander L.

Araceae (1.41)

Arum italicum Mill.

Arisarum vulgare O. Targ. Tozz. subsp. exertum Maire \& Weiller

G

57.1

Cst

Colocasia esculenta (L.) Schott.

Acc

Lemna minor $\mathrm{L}$.

Wolffia arrhiza (L.) Horkel ex Wimm.

Araliaceae (0.28)

Hedera helix $\mathrm{L}$.

Arecaceae (0.28)

Chamaerops humilis L.

$\mathrm{Ph}$

Aristolochiaceae (0.28) 


\begin{tabular}{|c|c|c|c|}
\hline $\begin{array}{l}\text { Family (RA \%) } \\
\text { Species }\end{array}$ & Life form & $\begin{array}{l}\text { Occ } \\
(\%)\end{array}$ & $\begin{array}{l}\text { Occ } \\
\text { scale }\end{array}$ \\
\hline Aristolochia paucinervis Pomel & $\mathrm{He}$ & 3.6 & Vac \\
\hline \multicolumn{4}{|l|}{ Asparagaceae (0.85) } \\
\hline Asparagus acutifolius L. & $\mathrm{Ph}$ & 21.4 & Acc \\
\hline Prospero autumnale (L.) Speta & $\mathrm{G}$ & 7.1 & Vac \\
\hline Ruscus hypophyllum L. & $\mathrm{Ch}$ & 39.3 & $\mathrm{Cmn}$ \\
\hline \multicolumn{4}{|l|}{ Aspleniaceae (0.28) } \\
\hline Asplenium adiantum-nigrum L. & $\mathrm{He}$ & 7.1 & Vac \\
\hline \multicolumn{4}{|l|}{ Asteraceae (6.78) } \\
\hline Anthemis arvensis $\mathrm{L}$. & $\mathrm{Th}$ & 21.4 & Acc \\
\hline Aster squamatus (Spreng.) Hieron. & $\mathrm{Hec}$ & 35.7 & $\mathrm{Cmn}$ \\
\hline Bellis aпnиа $\mathrm{L}$. & $\mathrm{Hec}$ & 92.9 & Cst \\
\hline Centaurea calcitrapa $\mathrm{L}$. & $\mathrm{Hec}$ & 10.7 & Vac \\
\hline Centaurea napifolia $\mathrm{L}$. & $\mathrm{Hec}$ & 3.6 & Vac \\
\hline Chamaemelum mixtum All. & $\mathrm{Th}$ & 75 & Cst \\
\hline Coleostephus myconis (L.) Cass ex Rchb. & Th & 32.1 & $\mathrm{Cmn}$ \\
\hline Conyza bonariensis (L.) Cronquist. & $\mathrm{Th}$ & 17.9 & Acc \\
\hline Cotula coronopifolia $\mathrm{L}$. & $\mathrm{He}$ & 50 & Cst \\
\hline Crepis vesicaria subsp. taraxacifolia (Thuill.) B.Boivin & $\mathrm{Hec}$ & 10.7 & Vac \\
\hline Dittrichia graveolens (L.) Greuter & $\mathrm{Th}$ & 7.1 & Vac \\
\hline Dittrichia viscosa L. Greuter & $\mathrm{Ch}$ & 14.3 & Acc \\
\hline Echinops spinosissimus Turra & $\mathrm{Hec}$ & 7.1 & Vac \\
\hline Filago pygmaea L. & $\mathrm{Th}$ & 7.1 & $\mathrm{Vac}$ \\
\hline Galactites tomentosa Moench & $\mathrm{Th}$ & 60.7 & Cst \\
\hline Hypochaeris radicata subsp. platylepis (Boiss.) Jahand. \& Maire & $\mathrm{Hec}$ & 32.1 & $\mathrm{Cmn}$ \\
\hline Lactuca viminea J. Presl \& C. Presl & $\mathrm{Hec}$ & 14.3 & Acc \\
\hline Logfia gallica Coss. \& Germ. & Th & 7.1 & Vac \\
\hline Plagius maghrebinus Vogt and Greuter & $\mathrm{Th}$ & 3.6 & Vac \\
\hline Scolymus hispanicus L. & $\mathrm{Hec}$ & 17.9 & Acc \\
\hline Senecio leucanthemifolius Poir. & $\mathrm{Th}$ & 17.9 & Acc \\
\hline Sonchus asper (L.) Hill. & $\mathrm{Th}$ & 3.6 & Vac \\
\hline Tolpis barbata (L.) Gaertn. & $\mathrm{Th}$ & 14.3 & Acc \\
\hline Xanthium spinosum $\mathrm{L}$. & $\mathrm{Th}$ & 25 & $\mathrm{Cmn}$ \\
\hline \multicolumn{4}{|l|}{ Athyriaceae (0.28) } \\
\hline Athyrium filix-femina (L.) Roth. & $\mathrm{Hec}$ & 64.3 & Cst \\
\hline \multicolumn{4}{|l|}{ Betulaceae (0.28) } \\
\hline Alnus glutinosa (L.) Gaertn. & $\mathrm{He}$ & 100 & Cst \\
\hline \multicolumn{4}{|l|}{ Boraginaceae (1.98) } \\
\hline Borago longifolia Poir. & $\mathrm{Th}$ & 3.6 & $\mathrm{Vac}$ \\
\hline
\end{tabular}




\begin{tabular}{|c|c|c|c|}
\hline $\begin{array}{l}\text { Family (RA \%) } \\
\text { Species }\end{array}$ & Life form & $\begin{array}{l}\text { Occ } \\
(\%)\end{array}$ & $\begin{array}{l}\text { Occ } \\
\text { scale }\end{array}$ \\
\hline Borago officinalis $\mathrm{L}$. & $\mathrm{Th}$ & 7.1 & Vac \\
\hline Cerinthe major $\mathrm{L}$. & Th & 10.7 & $\mathrm{Vac}$ \\
\hline Echium plantagineum $\mathrm{L}$. & $\mathrm{Hec}$ & 50 & Cst \\
\hline Myosotis ramosissima Rochel. & $\mathrm{Th}$ & 14.3 & Acc \\
\hline Myosotis sicula (Guss). & Th & 7.1 & Vac \\
\hline Pardoglossum cheirifolium (L.) E.Barbier \& Mathez & $\mathrm{Hec}$ & 39.3 & $\mathrm{Cmn}$ \\
\hline \multicolumn{4}{|l|}{ Brassicaceae (3.11) } \\
\hline Alliaria petiolata (M.Bieb) Cavara \& Grande & $\mathrm{Hec}$ & 25 & $\mathrm{Cmn}$ \\
\hline Biscutella didyma $\mathrm{L}$. & $\mathrm{Th}$ & 14.3 & Acc \\
\hline Brassica procumbens O.E. Schultz & Th & 10.7 & Vac \\
\hline Capsella bursa-pastoris (L.) Medik. & Th & 14.3 & Acc \\
\hline Cardamine hirsuta L. & $\mathrm{Th}$ & 3.6 & Vac \\
\hline Malcolmia ramosissima Thell. & $\mathrm{Th}$ & 10.7 & $\mathrm{Vac}$ \\
\hline Nasturtium officinale R. Br. & $\mathrm{Hec}$ & 71.4 & Cst \\
\hline Raphanus raphanistrum $\mathrm{L}$. & $\mathrm{Th}$ & 17.9 & Acc \\
\hline Rorippa amphibia Besser & $\mathrm{Hec}$ & 3.6 & Vac \\
\hline Sinapis arvensis L. & $\mathrm{Th}$ & 32.1 & $\mathrm{Cmn}$ \\
\hline Sinapis pubescens L. subsp. pubescens & $\mathrm{Th}$ & 10.7 & Vac \\
\hline \multicolumn{4}{|l|}{ Callitrichaceae (0.28) } \\
\hline Callitriche obtusangula Le Gall ex Hegelm. & Hy & 85.7 & Cst \\
\hline \multicolumn{4}{|l|}{ Campanulaceae (1.41) } \\
\hline Campanula alata Desf. & $\mathrm{Am}$ & 3.6 & Vac \\
\hline Campanula dichotoma $\mathrm{L}$. & $\mathrm{Th}$ & 14.3 & Acc \\
\hline Campanula rapunculus $\mathrm{L}$. & $\mathrm{Hec}$ & 3.6 & Vac \\
\hline Legousia falcata (Ten.) Fritsch & Th & 3.6 & Vac \\
\hline Solenopsis laurentia C. Presl. & $\mathrm{Th}$ & 50 & Cst \\
\hline \multicolumn{4}{|l|}{ Caprifoliaceae (0.85) } \\
\hline Dipsacus fullonum L. & $\mathrm{He}$ & 14.3 & Acc \\
\hline Fedia cornucopiae (L.) Gaertn. & $\mathrm{Th}$ & 25 & $\mathrm{Cmn}$ \\
\hline Viburnum tinus L. & $\mathrm{Ph}$ & 7.1 & Vac \\
\hline \multicolumn{4}{|l|}{ Caryophyllaceae (3.67) } \\
\hline Cerastium glomeratum Thuill. & $\mathrm{Th}$ & 46.4 & $\mathrm{Cmn}$ \\
\hline Cerastium semidecandrum L. & Th & 42.9 & $\mathrm{Cmn}$ \\
\hline Illecebrum verticillatum $\mathrm{L}$. & $\mathrm{Th}$ & 7.1 & Vac \\
\hline Paronychia argentea Lamk. & $\mathrm{Hec}$ & 25 & $\mathrm{Cmn}$ \\
\hline Polycarpon tetraphyllum L. & Th & 21.4 & Acc \\
\hline Silene coeli-rosa (L.) Godr. & Th & 50 & Cst \\
\hline Silene colorata Poir. & $\mathrm{Th}$ & 10.7 & Vac \\
\hline
\end{tabular}




\begin{tabular}{|c|c|c|c|}
\hline $\begin{array}{l}\text { Family (RA \%) } \\
\text { Species }\end{array}$ & Life form & $\begin{array}{l}\text { Occ } \\
(\%)\end{array}$ & $\begin{array}{l}\text { Occ } \\
\text { scale }\end{array}$ \\
\hline Silene gallica L. & $\mathrm{Hec}$ & 17.9 & Acc \\
\hline Silene vulgaris subsp. vulgaris (Moench.) Garcke. & $\mathrm{Hec}$ & 3.6 & Vac \\
\hline Spergula arvensis $\mathrm{L}$. & Th & 35.7 & $\mathrm{Cmn}$ \\
\hline Spergula fallax E.H.L. Krause & $\mathrm{He}$ & 17.9 & Acc \\
\hline Spergularia bocconei (Sheele) Asch. \& Graetn. & $\mathrm{Th}$ & 21.4 & Acc \\
\hline Stellaria media (L.) Vill & Th & 85.7 & Cst \\
\hline \multicolumn{4}{|l|}{ Ceratophyllaceae (0.28) } \\
\hline Ceratophyllum demersum L. & Hy & 14.3 & Acc \\
\hline \multicolumn{4}{|l|}{ Chenopodiaceae (0.28) } \\
\hline Chenopodium album L. & $\mathrm{He}$ & 14.3 & Acc \\
\hline \multicolumn{4}{|l|}{ Cistaceae (0.85) } \\
\hline Cistus monspeliensis L. & $\mathrm{Ph}$ & 3.6 & Vac \\
\hline Cistus salviifolius L. & $\mathrm{Ch}$ & 21.4 & Acc \\
\hline Halimium halimifolium Willk & $\mathrm{Ph}$ & 14.3 & Acc \\
\hline \multicolumn{4}{|l|}{ Compositeae (0.28) } \\
\hline Hyoseris radiata $\mathrm{L}$. & $\mathrm{Hec}$ & 17.9 & Acc \\
\hline \multicolumn{4}{|l|}{ Convolvulaceae (0.85) } \\
\hline Calystegia sepium (L.) R.Br & $\mathrm{Ph}$ & 82.1 & Cst \\
\hline Convolvulus althaeoides L. & G & 3.6 & Vac \\
\hline Convolvulus arvensis L. & G & 3.6 & Vac \\
\hline \multicolumn{4}{|l|}{ Crassulaceae (0.28) } \\
\hline Umbilicus rupestris (Salisb.) Dandy & $\mathrm{Hec}$ & 7.1 & Vac \\
\hline \multicolumn{4}{|l|}{ Cupressaceae (0.56) } \\
\hline Juniperus oxycedrus L. & $\mathrm{Ph}$ & 10.7 & Vac \\
\hline Taxodium distichum (L.) Rich. & $\mathrm{Ph}$ & 3.6 & Vac \\
\hline \multicolumn{4}{|l|}{ Cyperaceae (6.78) } \\
\hline Carex distans L. & $\mathrm{Hec}$ & 3.6 & $\mathrm{Vac}$ \\
\hline Carex divulsa Stoks. & $\mathrm{Hec}$ & 7.1 & $\mathrm{Vac}$ \\
\hline Carex elata All. & $\mathrm{Hec}$ & 28.6 & $\mathrm{Cmn}$ \\
\hline Carex flacca Shreb. & $\mathrm{Hec}$ & 7.1 & $\mathrm{Vac}$ \\
\hline Carex paniculata $\mathrm{L}$. & $\mathrm{Hec}$ & 3.6 & $\mathrm{Vac}$ \\
\hline Carex pendula Huds. & $\mathrm{Hec}$ & 25 & $\mathrm{Cmn}$ \\
\hline Carex pseudocyperus $L$. & $\mathrm{Hec}$ & 7.1 & Vac \\
\hline Carex punctata Gaudin & $\mathrm{Hec}$ & 42.9 & $\mathrm{Cmn}$ \\
\hline Carex remota $\mathrm{L}$. & $\mathrm{Hec}$ & 92.9 & Cst \\
\hline Carex sylvatica Huds. subsp. paui A. Bolòs \& O- Bòlos & $\mathrm{Hec}$ & 3.6 & $\mathrm{Vac}$ \\
\hline Carex vulpina $\mathrm{L}$. & $\mathrm{Hec}$ & 3.6 & Vac \\
\hline Cladium mariscus (L.) Pohl. & G & 25 & $\mathrm{Cmn}$ \\
\hline
\end{tabular}




\begin{tabular}{|c|c|c|c|}
\hline $\begin{array}{l}\text { Family (RA \%) } \\
\text { Species }\end{array}$ & Life form & $\begin{array}{l}\text { Occ } \\
(\%)\end{array}$ & $\begin{array}{l}\text { Occ } \\
\text { scale }\end{array}$ \\
\hline Cyperus esculentus $\mathrm{L}$. & $\mathrm{Th}$ & 21.4 & Acc \\
\hline Cyperus flavescens $\mathrm{L}$. & Th & 3.6 & Vac \\
\hline Cyperus fuscus L. & $\mathrm{Th}$ & 14.3 & Acc \\
\hline Cyperus longus L. subsp eu-longus Asch \& Gr. & $\mathrm{Hec}$ & 39.3 & $\mathrm{Cmn}$ \\
\hline Eleocharis palustris (L.) Roem. \& Schult. & $\mathrm{Hec}$ & 14.3 & Acc \\
\hline Fimbristylis squarrosa Vahl & Th & 3.6 & Vac \\
\hline Fuirena pubescens (Lam.) Kunth & $\mathrm{Hec}$ & 14.3 & Acc \\
\hline Isolepis cernua (Vahl) Roemer \& Schultes & Th & 67.9 & Cst \\
\hline Isolepis pseudosetacea (Daveau) Gand. & $\mathrm{Th}$ & 10.7 & Vac \\
\hline Schoenoplectus corymbosus (Roem. \& Schult.) A.Raynal & $\mathrm{Th}$ & 3.6 & $\mathrm{Vac}$ \\
\hline Schoenoplectus lacustris (L.) Palla & Hy & 17.9 & Acc \\
\hline Scirpoides holoschoenus (L.) Soják & $\mathrm{Hec}$ & 7.1 & Vac \\
\hline \multicolumn{4}{|l|}{ Dioscoreaceae (0.28) } \\
\hline Dioscorea communis (L.) Caddick \& Wilkin & G & 57.1 & Cst \\
\hline \multicolumn{4}{|l|}{ Dryopteridaceae (0.28) } \\
\hline Thelypteris interrupta (Willd.) Iwats. & $\mathrm{G}$ & 17.9 & Acc \\
\hline \multicolumn{4}{|l|}{ Equisetaceae (0.28) } \\
\hline Equisetum ramosissimum Desf. & G & 10.7 & $\mathrm{Vac}$ \\
\hline \multicolumn{4}{|l|}{ Ericaceae (0.56) } \\
\hline Erica arborea $\mathrm{L}$. & $\mathrm{Ph}$ & 42.9 & $\mathrm{Cmn}$ \\
\hline Erica scoparia L. & $\mathrm{Ph}$ & 25 & $\mathrm{Cmn}$ \\
\hline \multicolumn{4}{|l|}{ Euphorbiaceae (1.69) } \\
\hline Chamaesyce peplis (L.) Prokn. & Th & 7.1 & Vac \\
\hline Euphorbia biumbellata Poir. & $\mathrm{Ch}$ & 7.1 & Vac \\
\hline Euphorbia helioscopia L. & $\mathrm{Th}$ & 3.6 & Vac \\
\hline Euphorbia paralias L. & $\mathrm{Ch}$ & 7.1 & Vac \\
\hline Euphorbia terracina $\mathrm{L}$. & $\mathrm{Ch}$ & 3.6 & Vac \\
\hline Ricinus communis $\mathrm{L}$. & $\mathrm{Ph}$ & 10.7 & Vac \\
\hline \multicolumn{4}{|l|}{ Fabaceae (8.76) } \\
\hline Acacia dealbata Link & $\mathrm{Ph}$ & 7.1 & Vac \\
\hline Acacia melanoxylon $\mathrm{R} \cdot \mathrm{Br}$ & $\mathrm{Ph}$ & 3.6 & Vac \\
\hline Biserrula pelecinus $\mathrm{L}$. & $\mathrm{Ph}$ & 3.6 & Vac \\
\hline Calicotome villosa (Poir.) Link. & $\mathrm{Ph}$ & 57.1 & Cst \\
\hline Cytisus villosus Pourr. & $\mathrm{Ph}$ & 35.7 & $\mathrm{Cmn}$ \\
\hline Dorycnium rectum Ser. & $\mathrm{Hec}$ & 60.7 & Cst \\
\hline Erophaca baetica Boiss. & $\mathrm{Ph}$ & 7.1 & Vac \\
\hline Genista ferox (Poir.) Dum. Cours & $\mathrm{Ph}$ & 28.6 & $\mathrm{Cmn}$ \\
\hline Lotus biflorus Desr. & Th & 14.3 & Acc \\
\hline
\end{tabular}




\begin{tabular}{|c|c|c|c|}
\hline $\begin{array}{l}\text { Family (RA \%) } \\
\text { Species }\end{array}$ & Life form & $\begin{array}{l}\text { Occ } \\
(\%)\end{array}$ & $\begin{array}{l}\text { Occ } \\
\text { scale }\end{array}$ \\
\hline Lotus edulis L. & Th & 3.6 & Vac \\
\hline Lupinus angustifolius L. & $\mathrm{Th}$ & 21.4 & Acc \\
\hline Lupinus luteus L. & $\mathrm{Th}$ & 3.6 & Vac \\
\hline Medicago orbicularis (L.) Bartal. & $\mathrm{Th}$ & 3.6 & Vac \\
\hline Melilotus infestus Guss. & $\mathrm{He}$ & 10.7 & $\mathrm{Vac}$ \\
\hline Ornithopus pinnatus (Mill) Druce. & Th & 28.6 & $\mathrm{Cmn}$ \\
\hline Retama raetam subsp. bovei (Spach.) Talavera \& P.E. Gibbs & $\mathrm{Ph}$ & 3.6 & Vac \\
\hline Scorpiurus vermiculatus L. & Th & 3.6 & Vac \\
\hline Trifolium angustifolium $\mathrm{L}$. & $\mathrm{Th}$ & 10.7 & Vac \\
\hline Trifolium arvense $\mathrm{L}$. & $\mathrm{Th}$ & 3.6 & $\mathrm{Vac}$ \\
\hline Trifolium campestre Schreb. & $\mathrm{Th}$ & 25 & $\mathrm{Cmn}$ \\
\hline Trifolium micranthum Viv. & $\mathrm{Th}$ & 3.6 & Vac \\
\hline Trifolium pratense $\mathrm{L}$. & $\mathrm{Hec}$ & 3.6 & $\mathrm{Vac}$ \\
\hline Trifolium repens $\mathrm{L}$. & $\mathrm{Hec}$ & 92.9 & Cst \\
\hline Trifolium resupinatum L. & $\mathrm{Th}$ & 7.1 & Vac \\
\hline Trifolium squarrosum L. & Th & 7.1 & Vac \\
\hline Trifolium subterraneum L. & $\mathrm{Th}$ & 3.6 & $\mathrm{Vac}$ \\
\hline Vicia altissima Desf. & $\mathrm{Th}$ & 3.6 & Vac \\
\hline Vicia hirsuta (L.) Gray. & Th & 7.1 & Vac \\
\hline Vicia narbonensis L. & $\mathrm{Th}$ & 25 & $\mathrm{Cmn}$ \\
\hline Vicia sativa $\mathrm{L}$. & $\mathrm{Th}$ & 28.6 & $\mathrm{Cmn}$ \\
\hline Vicia sativa L. subsp. nigra (L.) Ehrh. & Th & 3.6 & Vac \\
\hline \multicolumn{4}{|l|}{ Fagaceae $(0.85)$} \\
\hline Quercus canariensis Willd. & $\mathrm{Ph}$ & 10.7 & $\mathrm{Vac}$ \\
\hline Quercus coccifera $\mathrm{L}$. & $\mathrm{Ph}$ & 25 & $\mathrm{Cmn}$ \\
\hline Quercus suber L. & $\mathrm{Ph}$ & 50 & Cst \\
\hline \multicolumn{4}{|l|}{ Funariaceae (0.28) } \\
\hline Funaria hygrometrica Hedw. & Bryophyte & 32.1 & $\mathrm{Cmn}$ \\
\hline \multicolumn{4}{|l|}{ Gentianaceae (0.56) } \\
\hline Centaurium erythraea Rafn. & $\mathrm{Hec}$ & 14.3 & Acc \\
\hline Schenkia spicata (L.) Mans. & G & 3.6 & Vac \\
\hline \multicolumn{4}{|l|}{ Geraniaceae (1.41) } \\
\hline Erodium botrys (Cav.) Bertol. & $\mathrm{Th}$ & 57.1 & Cst \\
\hline Erodium cicutarium (L.) l'Hér & $\mathrm{Th}$ & 17.9 & Acc \\
\hline Geranium dissectum L. & Th & 42.9 & $\mathrm{Cmn}$ \\
\hline Geranium molle L. & Th & 35.7 & $\mathrm{Cmn}$ \\
\hline Geranium robertianum L. & $\mathrm{Th}$ & 3.6 & $\mathrm{Vac}$ \\
\hline
\end{tabular}




\begin{tabular}{|c|c|c|c|}
\hline $\begin{array}{l}\text { Family (RA \%) } \\
\text { Species }\end{array}$ & Life form & $\begin{array}{l}\text { Occ } \\
(\%)\end{array}$ & $\begin{array}{l}\text { Occ } \\
\text { scale }\end{array}$ \\
\hline Hypericum afrum Lam. & $\mathrm{He}$ & 60.7 & Cst \\
\hline Hypericum perforatum $\mathrm{L}$. & $\mathrm{He}$ & 21.4 & Acc \\
\hline \multicolumn{4}{|l|}{ Hypolepidaceae (0.28) } \\
\hline Pteridium aquilinum (L.) Kuhn. & $\mathrm{G}$ & 89.3 & Cst \\
\hline \multicolumn{4}{|l|}{ Iridaceae (1.13) } \\
\hline Iris planifolia (Mill.) Fiori \& Paol. & G & 3.6 & $\mathrm{Vac}$ \\
\hline Iris pseudacorus $\mathrm{L}$. & G & 78.6 & Cst \\
\hline Iris unguicularis Poir. & $\mathrm{G}$ & 3.6 & $\mathrm{Vac}$ \\
\hline Romulea bulbocodium (L.) Sebast. \& Maur. & $\mathrm{G}$ & 7.1 & Vac \\
\hline \multicolumn{4}{|l|}{ Isoetaceae $(0.56)$} \\
\hline Cephaloceraton histrix (Bory \& Durieu) Gennari & $\mathrm{Hec}$ & 10.7 & $\mathrm{Vac}$ \\
\hline Isoetes velata A. Braun. & Hy & 25 & $\mathrm{Cmn}$ \\
\hline \multicolumn{4}{|l|}{ Juncaceae (3.11) } \\
\hline Juncus acutus L. & $\mathrm{Hec}$ & 10.7 & Vac \\
\hline Juncus articulatus L. & $\mathrm{Hec}$ & 7.1 & $\mathrm{Vac}$ \\
\hline Juncus bufonius L. & $\mathrm{Th}$ & 10.7 & $\mathrm{Vac}$ \\
\hline Juncus bulbosus L. & $\mathrm{Hec}$ & 17.9 & Acc \\
\hline Juncus capitatus Weigel & $\mathrm{Th}$ & 21.4 & Acc \\
\hline Juncus conglomeratus L. & $\mathrm{Hec}$ & 17.9 & Acc \\
\hline Juncus effusus L. & $\mathrm{Hec}$ & 46.4 & $\mathrm{Cmn}$ \\
\hline Juncus heterophyllus Dufour & $\mathrm{He}$ & 14.3 & Acc \\
\hline Juncus maritimus Lam. & $\mathrm{G}$ & 53.6 & Cst \\
\hline Juncus tenageia Ehrh. ex L.f. & $\mathrm{Hec}$ & 60.7 & Cst \\
\hline Luzula forsteri DC. & $\mathrm{Hec}$ & 3.6 & Vac \\
\hline \multicolumn{4}{|l|}{ Lamiaceae (3.39) } \\
\hline Calamintha nepeta (L.) Savi. & $\mathrm{Hec}$ & 3.6 & $\mathrm{Vac}$ \\
\hline Lamium bifidum Cirillo & $\mathrm{Hec}$ & 7.1 & $\mathrm{Vac}$ \\
\hline Lamium purpureum L. & Th & 3.6 & $\mathrm{Vac}$ \\
\hline Lavandula stoechas L. & $\mathrm{Ch}$ & 10.7 & $\mathrm{Vac}$ \\
\hline Lycopus europaeus L. & $\mathrm{Hec}$ & 75 & Cst \\
\hline Mentha aquatica L. & $\mathrm{Hec}$ & 14.3 & Acc \\
\hline Mentha pulegium L. & $\mathrm{Hec}$ & 75 & Cst \\
\hline Mentha suaveolens Ehrh. & $\mathrm{Hec}$ & 96.4 & Cst \\
\hline Prunella vulgaris L. & $\mathrm{Hec}$ & 7.1 & Vac \\
\hline Stachys arvensis L. & Th & 42.9 & $\mathrm{Cmn}$ \\
\hline Stachys marrubiifolia Viv. & $\mathrm{Th}$ & 7.1 & Vac \\
\hline Vitex agnus-castus L. & $\mathrm{Ch}$ & 3.6 & Vac \\
\hline
\end{tabular}

Lauraceae (0.28) 


\begin{tabular}{l}
\hline Family (RA \%) \\
Species \\
\hline Laurus nobilis L. \\
Lentibulariaceae (0.28)
\end{tabular}

Utricularia vulgaris L.

Linaceae (0.28)

Linum usitatissimum L. subsp angustifolium (Huds) Thell.

Lythraceae (0.85)

Lythrum hyssopifolia $\mathrm{L}$.

Lythrum junceum Banks \& Sol.

Lythrum salicaria L.

Malvaceae (0.56)

Lavatera cretica L.

Lavatera olbia L.

Moraceae (0.28)

Ficus carica L.

Myrsinaceae (0.85)

Anagallis arvensis L.

Anagallis crassifolia Thore

Anagallis monelli L.

Myrtaceae (0.85)

Eucalyptus camaldulensis Dehnh.

Eucalyptus gomphocephala D.C

Myrtus communis L.

Nympheaceae (0.28)

Nymphaea alba L.

Oleaceae (0.85)

Fraxinus angustifolia Vahl.

Olea europaea L. subsp. oleaster (Hoffmanns \& Link) Negodi.

Phillyrea latifolia L.

Onagraceae (0.85)

Circaea lutetiana L.

Epilobium hirsutum L.

Ludwigia palustris (L.) Elliot

Orobanchaceae (0.28)

Bellardia trixago (L.) All.

Osmundaceae (0.28)

Osmunda regalis $\mathrm{L}$.

Oxalidaceae (0.85)

Oxalis corniculata L.
Hy

Life form

$\mathrm{Ph}$

Hy

Th

Th

Th

$\mathrm{Hec}$

Th

Ch

$\mathrm{Ph}$

Th

Am

Th

$\mathrm{Ph}$

$\mathrm{Ph}$

$\mathrm{Ph}$

$\mathrm{Ph}$

$\mathrm{Ph}$

$\mathrm{Ph}$

G

$\mathrm{Hec}$

Th

Th

Hec

$\mathrm{Hec}$

h

,

c

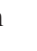

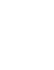

h

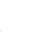

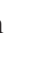

h

h

列

$\mathrm{Ph}$

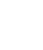

c

h

ec

c

Occ

(\%)

39.3

7.1

Vac

7.1

Vac

$$
3.6
$$

Vac

100

Cst

71.4

Cst

7.1

7.1

Vac

78.6

Cst

60.7

Cst

10.7

Vac

7.1

Vac

Vac

Acc

$35.7 \quad \mathrm{Cmn}$

$3.6 \quad \mathrm{Vac}$

Cst

$10.7 \quad$ Vac

64.3

Cst

50

Cst 


\begin{tabular}{|c|c|c|c|}
\hline $\begin{array}{l}\text { Family (RA \%) } \\
\text { Species }\end{array}$ & Life form & $\begin{array}{l}\text { Occ } \\
(\%)\end{array}$ & $\begin{array}{l}\text { Occ } \\
\text { scale }\end{array}$ \\
\hline Oxalis floribunda Lehm. & $\mathrm{Hec}$ & 7.1 & Vac \\
\hline Oxalis pes-caprae $\mathrm{L}$. & $\mathrm{Hec}$ & 14.3 & Acc \\
\hline \multicolumn{4}{|l|}{ Papaveraceae (0.56) } \\
\hline Fumaria capreolata $\mathrm{L}$. & Th & 25 & $\mathrm{Cmn}$ \\
\hline Glaucium flavum Crantz. & $\mathrm{Hec}$ & 3.6 & Vac \\
\hline \multicolumn{4}{|l|}{ Phytolaccaceae (0.28) } \\
\hline Phytolacca americana $\mathrm{L}$. & $\mathrm{Hec}$ & 17.9 & Acc \\
\hline \multicolumn{4}{|l|}{ Plantaginaceae (2.82) } \\
\hline Kickxia commutata (Rchb.) Fritsch. & Th & 21.4 & Acc \\
\hline Linaria flava Desf. & Th & 3.6 & Vac \\
\hline Linaria pinifolia Tell. & Th & 67.9 & Cst \\
\hline Linaria reflexa Desf. & $\mathrm{Th}$ & 17.9 & Acc \\
\hline Plantago crassifolia Forssk. & $\mathrm{Th}$ & 3.6 & Vac \\
\hline Plantago lanceolata $\mathrm{L}$. & $\mathrm{Hec}$ & 32.1 & $\mathrm{Cmn}$ \\
\hline Plantago macrorhiza Poir. & $\mathrm{Hec}$ & 21.4 & Acc \\
\hline Plantago major $\mathrm{L}$. & $\mathrm{Hec}$ & 10.7 & Vac \\
\hline Veronica agrestis $\mathrm{L}$. & $\mathrm{Th}$ & 35.7 & $\mathrm{Cmn}$ \\
\hline Veronica anagallis-aquatica $\mathrm{L}$. & Hy & 42.9 & $\mathrm{Cmn}$ \\
\hline \multicolumn{4}{|l|}{ Poacaeae (9.88) } \\
\hline Agrostis stolonifera L. & $\mathrm{Am}$ & 17.9 & Acc \\
\hline Alopecurus bulbosus Gouan & $\mathrm{Hec}$ & 14.3 & Acc \\
\hline Anthoxanthum odoratum $\mathrm{L}$. & $\mathrm{Hec}$ & 32.1 & $\mathrm{Cmn}$ \\
\hline Arundo donax $\mathrm{L}$. & $\mathrm{Hec}$ & 14.3 & Acc \\
\hline Avena sterilis $\mathrm{L}$. & $\mathrm{Th}$ & 7.1 & Vac \\
\hline Brachypodium distachyon (L.) P.Beauv. & $\mathrm{Hec}$ & 3.6 & Vac \\
\hline Brachypodium sylvaticum (Huds) P. Beauv. & $\mathrm{Hec}$ & 14.3 & Acc \\
\hline Briza maxima $\mathrm{L}$. & $\mathrm{Th}$ & 10.7 & Vac \\
\hline Briza minor $\mathrm{L}$. & $\mathrm{Th}$ & 25 & $\mathrm{Cmn}$ \\
\hline Bromus sterilis L. & $\mathrm{Th}$ & 3.6 & Vac \\
\hline Catapodium rigidum (L.) C.E. Hubb. & Th & 3.6 & Vac \\
\hline Cynodon dactylon (L.) Pers. & $\mathrm{Ch}$ & 7.1 & Vac \\
\hline Cynosurus elegans Desf. & $\mathrm{Th}$ & 3.6 & Vac \\
\hline Cynosurus polybracteatus Poir. & $\mathrm{Th}$ & 21.4 & Acc \\
\hline Dactyloctenium aegyptium (L.) Willd. & $\mathrm{Th}$ & 3.6 & $\mathrm{Vac}$ \\
\hline Digitaria sanguinalis (L) Scop. & $\mathrm{Th}$ & 32.1 & $\mathrm{Cmn}$ \\
\hline Echinochloa crus-galli (L.) P.Beauv. & $\mathrm{Th}$ & 3.6 & Vac \\
\hline Eragrostis atrovirens (Desf.) Trin. var. fontanesiano Emb. Maire. & $\mathrm{Hec}$ & 7.1 & Vac \\
\hline Glyceria fluitans (L.) R. Br. & Hy & 32.1 & $\mathrm{Cmn}$ \\
\hline
\end{tabular}




\begin{tabular}{|c|c|c|c|}
\hline $\begin{array}{l}\text { Family (RA \%) } \\
\text { Species }\end{array}$ & Life form & $\begin{array}{l}\text { Occ } \\
(\%)\end{array}$ & $\begin{array}{l}\text { Occ } \\
\text { scale }\end{array}$ \\
\hline Holcus lanatus L. & $\mathrm{Hec}$ & 28.6 & $\mathrm{Cmn}$ \\
\hline Hordeum murinum $\mathrm{L}$. & Th & 39.3 & $\mathrm{Cmn}$ \\
\hline Lagurus ovatus L. & $\mathrm{Th}$ & 7.1 & Vac \\
\hline Leersia oryzoïdes (L.) Sw. & $\mathrm{He}$ & 14.3 & Acc \\
\hline Lolium multiflorum Lam. & Th & 17.9 & Acc \\
\hline Mibora minima (L.) Desv. & $\mathrm{Th}$ & 3.6 & Vac \\
\hline Panicum repens $\mathrm{L}$. & $\mathrm{Ch}$ & 46.4 & $\mathrm{Cmn}$ \\
\hline Paspalum distichum $\mathrm{L}$. & $\mathrm{Hec}$ & 14.3 & Acc \\
\hline Phragmites australis (Cav.) Steud. & Hy & 35.7 & $\mathrm{Cmn}$ \\
\hline Piptatherum miliaceum (L.) Coss. & $\mathrm{Hec}$ & 7.1 & Vac \\
\hline Poa annua L. & $\mathrm{Th}$ & 57.1 & Cst \\
\hline Poa trivialis $\mathrm{L}$. & Th & 57.1 & Cst \\
\hline Polypogon monspeliensis (L.) Desf. & Th & 21.4 & Acc \\
\hline Polypogon viridis (Gouan) Breistr. & Th & 14.3 & Acc \\
\hline Puccinellia distans (Jacq.) Parl. & $\mathrm{Hec}$ & 3.6 & Vac \\
\hline Rostraria hispida (Savi) Dogan & $\mathrm{Th}$ & 10.7 & $\mathrm{Vac}$ \\
\hline \multicolumn{4}{|l|}{ Polygonaceae (1.98) } \\
\hline Persicaria decipiens (R. Br.) K. L. Wilson & Th & 57.1 & Cst \\
\hline Persicaria hydropiper (L.) Spach) & $\mathrm{Th}$ & 7.1 & Vac \\
\hline Persicaria lapathifolia (L.) Delarbre & $\mathrm{Th}$ & 89.3 & Cst \\
\hline Persicaria senegalensis (Meisn.) Soják & $\mathrm{Th}$ & 3.6 & Vac \\
\hline Rumex bucephalophorus L. & $\mathrm{Th}$ & 7.1 & $\mathrm{Vac}$ \\
\hline Rumex conglomeratus Murray & $\mathrm{Hec}$ & 71.4 & Cst \\
\hline Rumex pulcher L. & $\mathrm{Hec}$ & 14.3 & Acc \\
\hline \multicolumn{4}{|l|}{ Polypodiaceae (0.28) } \\
\hline Polypodium cambricum L. & Ep & 7.1 & $\mathrm{Vac}$ \\
\hline \multicolumn{4}{|l|}{ Potamogetonaceae (0.56) } \\
\hline Potamogeton nodosus Poir. & Hy & 28.6 & $\mathrm{Cmn}$ \\
\hline Potamogeton trichoides Cham. \& Schltdl & Hy & 10.7 & Vac \\
\hline \multicolumn{4}{|l|}{ Primulaceae (0.28) } \\
\hline Cyclamen africanum Boiss. \& Reut. & $\mathrm{G}$ & 14.3 & Acc \\
\hline \multicolumn{4}{|l|}{ Pteridaceae (0.28) } \\
\hline Adiantum capillus-veneris L. & $\mathrm{Hec}$ & 7.1 & Vac \\
\hline \multicolumn{4}{|l|}{ Ranunculaceae (3.67) } \\
\hline Clematis cirrhosa $\mathrm{L}$. & $\mathrm{Ph}$ & 10.7 & Vac \\
\hline Clematis flammula $\mathrm{L}$. & $\mathrm{Ph}$ & 21.4 & Acc \\
\hline Ficaria verna Huds. & $\mathrm{G}$ & 25 & $\mathrm{Cmn}$ \\
\hline Ranunculus bulbosus L. & $\mathrm{Hec}$ & 10.7 & Vac \\
\hline
\end{tabular}




\begin{tabular}{|c|c|c|c|}
\hline $\begin{array}{l}\text { Family (RA \%) } \\
\text { Species }\end{array}$ & Life form & $\begin{array}{l}\text { Occ } \\
(\%)\end{array}$ & $\begin{array}{l}\text { Occ } \\
\text { scale }\end{array}$ \\
\hline Ranunculus flammula $\mathrm{L}$. & $\mathrm{Hec}$ & 21.4 & Acc \\
\hline Ranunculus hederaceus $\mathrm{L}$. & Hy & 28.6 & $\mathrm{Cmn}$ \\
\hline Ranunculus macrophyllus Desf. & $\mathrm{Hec}$ & 71.4 & Cst \\
\hline Ranunculus muricatus L. & Th & 42.9 & $\mathrm{Cmn}$ \\
\hline Ranunculus ophioglossifolius Vill. & Th & 67.9 & Cst \\
\hline Ranunculus peltatus subsp. baudotii (Godr.) Meikle ex C.D.K.Cook & $\mathrm{Hec}$ & 7.1 & Vac \\
\hline Ranunculus sardous Crantz. & Th & 32.1 & $\mathrm{Cmn}$ \\
\hline Ranunculus sceleratus L. & $\mathrm{Th}$ & 85.7 & Cst \\
\hline Ranunculus trichophyllus Chaix. & Hy & 7.1 & Vac \\
\hline \multicolumn{4}{|l|}{ Rhamnaceae (0.28) } \\
\hline Frangula alnus Mill. & $\mathrm{Ph}$ & 28.6 & $\mathrm{Cmn}$ \\
\hline \multicolumn{4}{|l|}{ Rosaceae (2.26) } \\
\hline Crataegus azarolus L. & $\mathrm{Ph}$ & 3.6 & Vac \\
\hline Crataegus monogyna Jacq. & $\mathrm{Ph}$ & 39.3 & $\mathrm{Cmn}$ \\
\hline Potentilla reptans $\mathrm{L}$. & $\mathrm{Hec}$ & 46.4 & $\mathrm{Cmn}$ \\
\hline Prunus avium (L.) L. & $\mathrm{Ph}$ & 17.9 & Acc \\
\hline Rosa canina $\mathrm{L}$. & $\mathrm{Ph}$ & 3.6 & Vac \\
\hline Rosa sempervirens $\mathrm{L}$. & $\mathrm{Ph}$ & 17.9 & Acc \\
\hline Rubus ulmifolius Schott. & $\mathrm{Ph}$ & 96.4 & Cst \\
\hline Sanguisorba verrucosa (Link ex G.Don) Ces. & $\mathrm{Hec}$ & 3.6 & $\mathrm{Vac}$ \\
\hline \multicolumn{4}{|l|}{ Rubiaceae (1.13) } \\
\hline Galium elongatum C.Presl & $\mathrm{Hec}$ & 60.7 & Cst \\
\hline Galium scabrum L. & $\mathrm{Hec}$ & 3.6 & $\mathrm{Vac}$ \\
\hline Rubia peregrina $\mathrm{L}$. & $\mathrm{Hec}$ & 78.6 & Cst \\
\hline Sherardia arvensis $\mathrm{L}$. & $\mathrm{Th}$ & 42.9 & $\mathrm{Cmn}$ \\
\hline \multicolumn{4}{|l|}{ Salicaceae (1.13) } \\
\hline Populus nigra L. & $\mathrm{Ph}$ & 3.6 & $\mathrm{Vac}$ \\
\hline Salix alba L. & $\mathrm{Ph}$ & 50 & Cst \\
\hline Salix atrocinerea Brot. & $\mathrm{Ph}$ & 21.4 & Acc \\
\hline Salix pedicellata Desf. & $\mathrm{Ph}$ & 64.3 & Cst \\
\hline \multicolumn{4}{|l|}{ Salviniaceae (0.28) } \\
\hline Salvinia natans (L.) All. & Hy & 3.6 & Vac \\
\hline \multicolumn{4}{|l|}{ Scrophulariaceae (0.85) } \\
\hline Scrophularia sambucifolia L. subsp. mellifera Maire & $\mathrm{Hec}$ & 35.7 & $\mathrm{Cmn}$ \\
\hline Scrophularia tenuipes Coss \& Durieu & $\mathrm{Hec}$ & 10.7 & $\mathrm{Vac}$ \\
\hline Verbascum sinuatum L. & $\mathrm{Hec}$ & 10.7 & $\mathrm{Vac}$ \\
\hline \multicolumn{4}{|l|}{ Selaginellaceae (0.28) } \\
\hline Selaginella kraussiana (Kunze) A. Braun & $\mathrm{He}$ & 3.6 & $\mathrm{Vac}$ \\
\hline
\end{tabular}




\begin{tabular}{|c|c|c|c|}
\hline $\begin{array}{l}\text { Family (RA \%) } \\
\text { Species }\end{array}$ & Life form & $\begin{array}{l}\text { Occ } \\
(\%)\end{array}$ & $\begin{array}{l}\text { Occ } \\
\text { scale }\end{array}$ \\
\hline \multicolumn{4}{|l|}{ Smilacaceae (0.28) } \\
\hline Smilax aspera $\mathrm{L}$. & $\mathrm{Ph}$ & 89.3 & Cst \\
\hline \multicolumn{4}{|l|}{ Solanaceae (1.13) } \\
\hline Datura stramonium L. & Th & 28.6 & $\mathrm{Cmn}$ \\
\hline Solanum dulcamara $\mathrm{L}$. & $\mathrm{Ph}$ & 32.1 & $\mathrm{Cmn}$ \\
\hline Solanum linnaeanum Hepper \& P.-M.L.Jaeger & $\mathrm{Hec}$ & 10.7 & Vac \\
\hline Solanum nigrum $\mathrm{L}$. & Th & 50 & $\mathrm{Cmn}$ \\
\hline \multicolumn{4}{|l|}{ Sphagnaceae (0.28) } \\
\hline Sphagnum subsecundum var. auriculatum (Schimp.) Schlieph. & $\mathrm{He}$ & 3.6 & Vac \\
\hline \multicolumn{4}{|l|}{ Tamaricaceae (0.28) } \\
\hline Tamarix canariensis Willd. & $\mathrm{Ph}$ & 7.1 & $\mathrm{Vac}$ \\
\hline \multicolumn{4}{|l|}{ Thymeleaceae (0.28) } \\
\hline Daphne gnidium L. & $\mathrm{Ph}$ & 17.9 & Acc \\
\hline \multicolumn{4}{|l|}{ Thyphaceae (0.28) } \\
\hline Sparganium erectum $\mathrm{L}$. & Нy & 14.3 & Acc \\
\hline \multicolumn{4}{|l|}{ Ulmaceae (0.28) } \\
\hline Ulmus minor Mill. & $\mathrm{Ph}$ & 21.4 & Acc \\
\hline \multicolumn{4}{|l|}{ Urticaceae (0.56) } \\
\hline Urtica dioica $\mathrm{L}$. & $\mathrm{Hec}$ & 14.3 & Acc \\
\hline Urtica membranacea Poir. & Th & 3.6 & $\mathrm{Vac}$ \\
\hline \multicolumn{4}{|l|}{ Verbenaceae $(0.28)$} \\
\hline Verbena officinalis L. & $\mathrm{Hec}$ & 25 & $\mathrm{Cmn}$ \\
\hline \multicolumn{4}{|l|}{ Violaceae (0.28) } \\
\hline Viola alba subsp. denhardtii (Ten.) W. Becker. & Th & 7.1 & Vac \\
\hline \multicolumn{4}{|l|}{ Vitaceae $(0.28)$} \\
\hline Vitis vinifera subsp. sylvestris (C.C.Gmel.) Hegi & $\mathrm{Ph}$ & 67.9 & Cst \\
\hline \multicolumn{4}{|l|}{ Xanthorrhoeaceae (0.28) } \\
\hline Asphodelus aestivus Brot. & $\mathrm{Hec}$ & 28.6 & $\mathrm{Cmn}$ \\
\hline
\end{tabular}

